\title{
Environmental Effects on Long Term Displacement Data of Woven Fabric Webbings under Constant Load for Inflatable Structures
}

\author{
Winfred S. Kenner ${ }^{1}$, Thomas C. Jones ${ }^{2}$, and William R. Doggett ${ }^{3}$ \\ NASA Langley Research Center, Hampton, Virginia, 23681-2199 \\ Quinton Duncan ${ }^{4}$, and James Plant ${ }^{5}$ \\ NASA Langley Research Center, Hampton, Virginia, 23681-2199
}

\begin{abstract}
An experimental study of the effects of environmental temperature and humidity conditions on long-term creep displacement data of high strength Kevlar and Vectran ${ }^{\mathrm{TM}}$ woven fabric webbings under constant load for inflatable structures is presented. The restraint layer of an inflatable structure for long-duration space exploration missions is designed to bear load and consists of an assembly of high strength webbings. Long-term creep displacement data of webbings can be utilized by designers to validate service life parameters of restraint layers of inflatable structures. Five groups of high-strength webbings were researched over a two year period. Each group had a unique webbing length, load rating, applied load, and test period. The five groups consisted of 1.) $6 \mathrm{~K}$ Vectran webbings loaded to $49 \%$ ultimate tensile strength (UTS), 2.) $6 \mathrm{~K}$ Vectran webbings loaded to $55 \%$ UTS, 3.) $12.5 \mathrm{~K}$ Vectran webbings loaded to $22 \%$ UTS, 4.) $6 \mathrm{~K}$ Kevlar webbings loaded to $40 \%$ and $43 \%$ UTS, and 5.) $6 \mathrm{~K}$ Kevlar webbings loaded to 48\% UTS. Results show that all webbing groups exhibit the initial two stages of three of a typical creep curve of an elastic material. Results also show that webbings exhibit unique local wave patterns over the duration of the test period. Data indicate that the local pattern is primarily generated by daily variations in relative humidity values within the test facility. Data indicate that after a three to six month period, where webbings reach a steady-state creep condition, an annual sinusoidal displacement pattern is exhibited, primarily due to variations in annual mean temperature values. Data indicates that variations in daily temperature values and annual mean humidity values have limited secondary effects on creep displacement behavior. Results show that webbings in groups 2 and 5 do not exhibit well defined annual displacement patterns because the magnitude of the applied loads cause large deformations, and data indicate that material yielding within a webbing tends to neutralize the annual sinusoidal displacement pattern. Study indicates that applied load, environmental effects, mechanical strength, coefficient of thermal expansion, and hygroscopic properties of webbings are fundamental requirements for quantifying accurate creep displacements and behaviors over multiple year time periods. Results from a study of the environmental effects on long-term creep displacement data of Kevlar and Vectran woven webbings are presented to increase the knowledge base of webbing materials and to enhance designs of inflatable space structures for long-duration space missions.
\end{abstract}

\footnotetext{
${ }^{1}$ Aerospace Engineer, Structural Mechanics and Concepts Branch, Mail Stop 190

${ }^{2}$ Aerospace Engineer, Structural Mechanics and Concepts Branch, Mail Stop 190

${ }^{3}$ Aerospace Engineer, Structural Mechanics and Concepts Branch, Mail Stop 190

${ }^{4}$ Lead Engineering Technician, Structures Experiments Branch, Mail Stop 188F

${ }^{5}$ Engineering Technician, Materials Experiment Branch, Mail Stop 419
} 


\section{Nomenclature}

$\begin{array}{ll}r & =\text { radius } \\ P & =\text { pressure } \\ \mathrm{t} & =\text { thickness } \\ \sigma_{\mathrm{h}} & =\text { hoop stress } \\ \sigma_{\mathrm{l}} & =\text { longitudinal stress } \\ \mathrm{FS} & =\text { Factor of Safety } \\ \mathrm{HVAC} & =\text { Heating, Ventilation, and Air Conditioning } \\ \mathrm{M} / \mathrm{L} & =\text { mass per unit length }\end{array}$

\section{Introduction}

$I^{\mathrm{n}}$ nflatable space structures have been utilized in various aerospace applications [1-6] for over 30 years. Three examples of inflatable aerospace structures are shown in Figure 1. Inflatable space modules, a subset of inflatable structures, are currently being developed by NASA and private companies for potential weight and launch volume savings relative to metallic space modules. Current metallic space modules are limited in size to the diameter of the launch vehicle. An inflatable space module can uniquely be stowed in a small volume, and deployed on orbit to provide an increased working volume for astronauts (Fig. 2). They can also be designed for lunar or Mars surface applications at lower costs than metallic structures. An inflatable module technology demonstrator for surface application is presented in Figure. 3. Inflatable modules are typically designed with cylindrical or spherical configurations to simplify material and structural analyses (Fig. 4.).

Along with desirable characteristics, inflatable modules have notable risk factors. The walls of inflatable space modules are typically constructed of the following three layers: 1) an internal gas retention layer consisting of a flexible bladder, 2) a load-bearing restraint layer which typically consists of high strength woven materials or webbings, and 3) an attenuation barrier consisting of radiation, thermal, and micrometeoroid and orbital debris (MMOD) layers. When an inflatable module is deployed on orbit to a defined internal pressure the wall or shell loads are primarily carried by the restraint layer. Over extended periods of time these loads can potentially cause the restraint layer to creep, degrade, and fail. Definition of stresses and strains within a restraint layer, and definition of viable restraint layer materials that can sustain loads over extended periods of time are necessary for designers to validate material performance and predict service life of inflatable modules. Proposed inflatable space modules are envisioned to have a service life that is comparable to the service life of metallic space modules. The study and characterization of the creep behavior of restraint layer materials offers a means to mitigate the risk of degradation and failure, and achieve a long-life for an inflatable module.

The database of material and mechanical properties of woven materials for aerospace application is substantially smaller than the comparable database of mechanical properties for metallic or composite materials. In general, aerospace designers and engineers rely on well-defined material properties in the conceptual and developmental phases of new aerospace structures. Designers also apply a factor of safety to final designs to lower the risk introduced by structural degradation under complex loading. Metals are often considered ideal materials for aerospace structures because they have well defined material properties across a wide range of thermo-mechanical loads. The use of A-basis or B-basis material allowable strength values within a structural design is one of the best means to lower risk and insure structural viability. A-basis allowable strength values are available for most aluminum alloys and in general B-basis allowable strength values are available for common autoclave polymer matrix composite materials (Fig. 5). High strength woven materials for space applications typically consist of flexible synthetic interwoven fibers, and are defined as viscoelastic. Viscoelastic materials exhibit nonlinear behavior during initial load application and over time [6]. Mechanical properties of woven materials are typically generated per roll of material through experimental testing. Limited data exist on environmental effects on long-term creep displacement behavior of woven fabric materials under load.

Current interest in the behavior of webbings evolved from previous lightweight material projects [7-8] and programs conducted at National Aeronautics and Space Administration (NASA) Langley Research Center (LaRC) and Johnson Space Center (JSC). NASA initiated the Structures, Materials, and Mechanisms, (SMM) project under the Exploration Technology Development Program (ETDP) at LaRC in 2007 to develop viable lightweight materials for space exploration, which included the development of technologies for advancement of lightweight inflatable habitat structures. The Ultimate Tensile Strength (UTS) of both pristine and damaged webbings, as well as thermal effects were studied. Another technical task under SMM researched lightweight parachute materials for the Orion space capsule, with the development of high strength fibers and yarns as a focus. The SMM project also leveraged previous inflatable module work from the JSC TransHab (1988-1998) program. The TransHab program investigated 
the possible use of an inflatable module, as a enclosed environment for human habitatation, on the International Space Station (ISS). Work included inflatable module deployment procedures, internal hardware layout, and a review of viable materials for the multilayered inflatable shell. Kevlar was selected as the baseline restraint layer material for Transhab, and a database of mechanical properties was generated via a wide range of experimental tests.

The current study was conducted within the Lightweight, Materials, and Structures (LMS) project under the Game Changing Development Program (GCDP) at NASA LaRC to research the long term effects of varying environmental conditions on the creep behavior of high strength webbings under constant load. Webbing materials are sensitive to temperature variations, and they are hygroscopic, readily absorbing and releasing moisture. They respond to daily and seasonal changes in temperature and humidity by expanding and contracting. Since dimensional changes in the webbing material can accelerate deterioration, the characterization of environmental effects on the creep behavior of webbings is desirable by designers to validate service life parameters.

\section{Approach}

\section{A. Objective}

The objective of this study is to characterize the environmental effects of ambient air temperature and relative humidity on the long-term progressive deformation of high strength webbings under medium and high applied loads. Two high strength webbing materials were selected for study, Kevlar and Vectran. Kevlar was studied to leverage previous work conducted under the Transhab program. Vectran was studied due to its advertised improved creep life performance properties over Kevlar.

\section{B. Creep Theory in Polymer Webbings}

Creep is the progressive deformation of a material held at a constant load. Creep behavior has three classic stages; primary, secondary, and tertiary (Fig. 6). Primary creep is a transient stage during which the material deforms at a decreasing strain rate. Deformation is primarily elastic, but the total creep strain is only partially recoverable, therefore some plastic deformation is also present. Deformation occurs at a molecular level in aligning the polymer backbones within the crystal structure, through slip and chain-direction shear. Webbing materials exhibit decrimping and fiber locking during the primary stage with the amount of recovery at both levels dependent on applied load. The primary creep stage may be of relatively short duration due to the highly oriented polymeric structure already present in webbings, since the majority of chain alignments have been accomplished during processing of the polymeric fibers. Webbing materials may exhibit near constant creep strain rates over an extended time period during the secondary stage. Positively-sloped creep strain rates equate to a gradual reduction in the strain rate in linear time, which suggests a strain hardening of the material throughout its time to failure. Materials would classically exhibit necking during the tertiary phase, which reduces the cross-sectional area of the specimen, leading to higher local stresses and a rapidly increasing strain rate until failure. The Poisson necking effect is very small for high strength webbing due to a very low percentage of fill yarns, therefore a typical tertiary stage is not prominent.

\section{Specimen Description}

High strength Kevlar and Vectran webbing materials were selected for testing in this study. Webbings are customized long narrow straps of woven material. The restraint layer of an inflatable structure can consist of hundreds or thousands of webbings. In general a segment of webbing consist of vertical warp yarns with horizontal fill yarns woven together in a defined $0^{\circ}$ and $90^{\circ}$ angle pattern. A typical roll and a flat segment of Vectran webbing are shown in Figure 7. Kevlar and Vectran webbings are manufactured in runs of several thousand yards from which rolls of 25 to 60 yards of material are cut. The test material webbings for this study consist of: 1.) Kevlar nominally rated for 6,000 lbs/inch, 2.) Vectran nominally rated for 6,000 lbs/inch and 3.) Vectran nominally rated for 12,500 lbs/inch, henceforth referred to as "6K Kevlar", "6K Vectran", and "12.5K Vectran", respectively. All webbings are 1-inch wide, and material specifications for $6 \mathrm{~K}$ and $12.5 \mathrm{~K}$ webbings are presented in Table 1 . The Mil-T-87130 manufacturing specifications for the $6 \mathrm{~K}$ and $12.5 \mathrm{~K}$ webbings are presented in Table 2. Note, the former Mil-T87130 USAF military specification has now been reissued as a Parachute Industry Association specification, PIA-T87130B. Kevlar is an aromatic polyamide, or aramid, which is a lyotropic liquid crystal polymer (LCP), where the liquid crystalline phase exists upon dissolution of the polymer in a solvent. The lyotropic LPC is then spun into fibers, with the liquid crystalline order resulting in a highly oriented fiber structure. Mil-T-87130 was created for para-aramids, which are long chain aramids that include Kevlar, Technora and Twaron. Vectran is not an aramid, but rather an aromatic polyester which is a thermotropic LCP, where the liquid crystalline phase is exhibited over a 
particular temperature range. Vectran fibers are created through melt-spinning involving extrusion through a die. $\mathrm{M} / \mathrm{L}$ is a unit conversion from oz/yd and it is the maximum allowed mass per unit length to meet the specification.

Kevlar and Vectran webbing manufacturers provide a strength rating per roll of material. The provided strength value is typically conservative. Determination of an accurate strength value per roll provides guidance on allowable applied loads for long duration testing. Five webbings per roll were tested to failure, and the failure loads were averaged to obtain an average UTS value per roll. The UTS testing follows the ASTM-D-6775-02 standard test method for breaking strength and elongation of textile webbing, tape and braided material. Material strength tests were conducted on all webbing rolls utilized in this study by Jones [7] on a standard 55 kip load machine in a separate test facility. Material strength values per test group are presented in Table 3.

Kevlar and Vectran webbings also have intrinsic coefficient of thermal expansion (CTE) and coefficient of hygroscopic expansion (CHE) values per roll. CTE is a thermal property which characterizes the degree of expansion or contraction of a material when heated or cooled, and CHE is a chemical property which characterizes the degree a material can attract water molecules from the surrounding air through absorption or adsorption. CTE and CHE values per roll were not provided by the manufacturer, however CTE values by fiber are available on the manufacturer's website. It is known from previous studies [7-8] that both webbing materials have negative CTE values. CHE values for the webbing materials in this study were not defined.

Table 1. Material specifications for $6 \mathrm{~K}$ and $12.5 \mathrm{~K}$ Kevlar and Vectran webbings.

\begin{tabular}{|c|c|c|c|}
\hline Webbing & $6 \mathrm{~K}$ Kevlar & 6K Vectran & $12.5 \mathrm{~K}$ Vectran \\
\hline Type & $\begin{array}{l}1991-1 \text { " } \\
\text { Natural "R" } \\
\text { Kevlar tape }\end{array}$ & $\begin{array}{ll}6996-1 " & \text { Natural } \\
\text { "R" } & \text { Vectran } \\
6,000 \text { lb } & \text { webbing } \\
\end{array}$ & $\begin{array}{l}1 " \quad \text { Natural Vectran } \\
\text { webbing (100\% Vectran) }\end{array}$ \\
\hline Spec & $\begin{array}{l}\text { Mil-T-87130 Type } \\
\text { VI Class } 9 \text { Mod to R }\end{array}$ & $\begin{array}{l}\text { Mil-T-87130 } \\
\text { Type VI Class } 9 \\
\text { Mod to R }\end{array}$ & $\begin{array}{l}\text { Mil-T-87130 Type VI } \\
\text { Class 11 Mod to R }\end{array}$ \\
\hline Put-up & $\begin{array}{l}60 \text { Yard Rolls, } 15 \\
\text { Yard Mutts }(+1 /-0)\end{array}$ & $\begin{array}{l}25 \text { yard rolls } \\
(-0 /+1)\end{array}$ & 50 yard rolls \\
\hline Vendor & Bally Ribbon & Bally Ribbon & $\begin{array}{l}\text { Offray Specialty Narrow } \\
\text { Fabrics }\end{array}$ \\
\hline Finish & Sil-W- & 5E “R" - Polyvil & Butyral Resin \\
\hline
\end{tabular}

Table 2. Mil-T-87130 manufacturing specifications for $6 \mathrm{~K}$ and $12.5 \mathrm{~K}$ webbings.

\begin{tabular}{|c|c|c|c|c|c|c|c|c|c|c|c|c|}
\hline \multicolumn{4}{|c|}{ Mil-T-87130 Specification } & \multicolumn{3}{|c|}{ Lineal Density } & \multicolumn{6}{|c|}{ WARP (Axial Threads) Properties } \\
\hline $\begin{array}{l}\text { Minimum } \\
\text { UTS } \\
\text { (lbs) }\end{array}$ & $\begin{array}{l}\text { Width } \\
\text { (inches }\end{array}$ & Гуре & Class & $\begin{array}{l}\text { Max } \\
\text { Wt } \\
\text { (oz/yd) }\end{array}$ & $\begin{array}{c}\text { Max } \\
\text { M/L } \\
\text { (lbs/in) }\end{array}$ & $\begin{array}{c}\text { Total } \\
\mathrm{M} / \mathrm{L}\end{array}$ & Denier & Ply & $\begin{array}{l}\text { Total } \\
\text { Ends } \\
\text { Minimum }\end{array}$ & $\begin{array}{c}\text { Fiber } \\
\text { M/L } \\
\text { (lbs/in) }\end{array}$ & $\begin{array}{l}\text { Warp } \\
\text { (lbs/in) }\end{array}$ & $\begin{array}{l}\% \text { Warp } \\
\text { by mass }\end{array}$ \\
\hline 6000 & 1 & VI & 9 & 1 & 0.001736 & 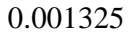 & 1500 & 3 & 44 & 9.333E-06 & & 6 \\
\hline 12500 & 1 & VI & 11 & 1.65 & 0.002865 & 0.002576 & 1500 & 3 & 89 & $9.333 \mathrm{E}-06$ & 0.002492 & 0.9674 \\
\hline
\end{tabular}

\begin{tabular}{|c|c|c|c|c|c|c|c|c|c|}
\hline \multicolumn{4}{|c|}{ Mil-T-87130 Specification } & \multicolumn{6}{|c|}{ FILL or WEFT (Cross Threads) Properties } \\
\hline $\begin{array}{l}\text { Minimum } \\
\text { UTS } \\
\text { (lbs) }\end{array}$ & $\begin{array}{c}\text { Width } \\
\text { (inches) }\end{array}$ & Type & Class & Denier & Ply & $\begin{array}{l}\text { Picks } \\
\text { (per } \\
\text { inch) } \\
\end{array}$ & $\begin{array}{l}\text { Fiber } \\
\text { M/L } \\
\text { (lbs/in) }\end{array}$ & $\begin{array}{l}\text { Weft } \\
\text { M/L } \\
\text { (lbs/in) }\end{array}$ & $\begin{array}{l}\text { \% Fill } \\
\text { by mass }\end{array}$ \\
\hline 6000 & 1 & VI & 9 & 1500 & 1 & 10 & $9.333 \mathrm{E}-06$ & $9.333 \mathrm{E}-05$ & 0.0704 \\
\hline 12500 & 1 & VI & 11 & 1500 & 1 & 9 & $9.333 \mathrm{E}-06$ & 8.3996E-05 & 0.0326 \\
\hline
\end{tabular}

Table 3. Strength values per webbing material roll for webbing groups 1-5.

\begin{tabular}{|l|l|l|l|}
\hline $\begin{array}{l}\text { Group } \\
\#\end{array}$ & $\begin{array}{l}\text { Webbing } \\
\text { Materials }\end{array}$ & $\begin{array}{l}\text { Load rating per } \\
\text { webbing roll (lbs) }\end{array}$ & $\begin{array}{l}\text { UTS per } \\
\text { webbing roll (lbs) }\end{array}$ \\
\hline 1 & Vectran & 6000. & 6123. \\
\hline 2 & Vectran & 6000. & 5867. \\
\hline 3 & Vectran & 12500. & 15933. \\
\hline 4 & Kevlar & 6000. & 7038. \\
\hline 5 & Kevlar & 6000. & 7038. \\
\hline
\end{tabular}

4

American Institute of Aeronautics and Astronautics 


\section{Experimental Setup}

All creep tests were conducted in an enclosed 20 -foot by 30 -foot high bay facility at NASA LaRC. Three rows of large-scale I-beam structures were designed and assembled to enable testing of numerous webbing materials (Figures 8-10). Experimental test hardware consisted of: three rows of steel I-beam structures, concrete weights, landing platforms for concrete weights, upper and lower webbing restraint fixtures, and displacement transducer sensors. Two types of concrete weights were utilized to load the webbings: 1.) 1800-lbs concrete block, and 2.) $2800-1 b s$ concrete culvert. The $1800-1 b s$ concrete weight has a 2 by 2 by 3 -foot block geometry, and the $2800-1 b s$ concrete culvert has an 8 -foot long by 32 -inch diameter cylindrical geometry. The I-beam structure in row one is $14-$ feet tall, the I-beam structure in row two is 12 -feet tall, and the I-beam structure in row three is 20 -feet tall. The height per I-beam structure is proportional to the height of the associated concrete weight. Creep tests from rows one (14 feet) and three (20 feet) were selected for this study because both rows have I-beams with displacement sensors. The test facility lacks an HVAC control system, therefore environmental factors should have a more severe effect on webbing displacements, versus a facility that is equipped with an HVAC system.

The webbing installation procedure per restraint fixture (Fig. 11a, b), consist of wrapping the top end of a webbing around the two pins of the upper restraint fixture and wraping the lower end around the lower restraint fixture. Both restraint fixtures and webbing stabilize after application of a tension load by suspension of the applied weight. The upper restraint fixture is attached to an I-beam clamp, which is attached to the lower flange of the cantilevered I-beam, and the lower restraint fixture is attached to the concrete weight.

The acquisition of continuous displacement data over multiple years is required for the study of environmental effects on webbing displacements. Linear displacement transducer sensors (Fig. 11c) were utilized to measure webbing displacements. Test setup methodology is illustrated in Figure 12, and Prior to the test start anchor and cable hardware appenditure are attached to the upper restraint fixture. Next, the transducer is attached to the lower restraint fixture. Transducer heads are both extendable and retractable. The head of the transducer is attached to the cable. Slack in the cable during setup is desired so that the head of the transducer isn't pulled out or otherwise damaged. Once the webbing and hardware are aligned, slack in the transducer cable is removed. Note however that a level of slack does exist in the transducer cable, which makes obtaining an initial webbing length difficult. The weight is suspended and the webbing experiences displacement which coincides with the extension of the transducer head. The test has initiated at this point in time. The longitudinal wave motion of the webbing due to environmental effects is illustrated in Figure 13. Transducer head extension or contraction is a measure of webbing extension or contraction due to the applied weight, and environmental effects, and these values are defined as webbing displacement data. Output voltage data from each transducer was recorded on a stand-alone real time data logger. Data was recorded at a rate of once per second during the initial day of webbing suspension, and reduced to once an hour after the fourth or fifth day of webbing suspension. Several types of transducers were utilized in this study due to limited project funds and vendor supply. The minimum full scale stroke range, of all transducers, was four inches and the maximum range was six inches. All utilized transducers had an accuracy of at least $1 \%$ full scale.

\section{E. Test Matrix}

Five test groups of high strength webbings were defined for this study. Each test group had a unique webbing length, load rating, applied load, and test period. Applied loads and load rating UTS (lbs), per test group are presented in Table 4, and webbing length and test start and dates of last recorded data are presented in the test matrix in Table 5. The five test groups consisted of; 1.) three 6K Vectran webbings load to $49 \%$ UTS, 2.) three 6K Vectran webbings loaded to 55\% UTS, 3.) two $12.5 \mathrm{~K}$ Vectran webbings loaded to $22 \% \mathrm{UTS}$, 4.) three $6 \mathrm{~K}$ Kevlar webbings loaded to $40 \%$ and $43 \%$ UTS, and 5.) three $6 \mathrm{~K}$ Kevlar webbings loaded to $48 \%$ UTS. The UTS (\%) value presented in Table 4 is the applied load divided by the webbing roll average UTS (lbs) value multiplied by $100 \%$. Webbings are of different length per group due to the relative heights of applied weights and support structure.

Table 4. Applied load and UTS\% calculations per webbing for webbing groups 1-5.

\begin{tabular}{|c|c|c|c|c|c|c|c|c|c|c|c|c|c|c|c|c|}
\hline \multicolumn{2}{|c|}{ Group \# } & \multicolumn{3}{|c|}{ Group 1} & \multicolumn{3}{|c|}{ Group 2} & \multicolumn{3}{|c|}{ Group 3} & \multicolumn{3}{|c|}{ Group 4} & \multicolumn{3}{|c|}{ Group 5} \\
\hline \multicolumn{2}{|c|}{ Material } & \multicolumn{3}{|c|}{$6 \mathrm{~K}$ Vectran } & \multicolumn{3}{|c|}{$6 \mathrm{~K}$ Vectran } & \multicolumn{3}{|c|}{$12.5 \mathrm{~K}$ Vectran } & \multicolumn{3}{|c|}{ 6K Kevlar } & \multicolumn{3}{|c|}{ 6K Kevlar } \\
\hline \multicolumn{2}{|c|}{$\begin{array}{l}\text { UTS } \%=\text { Load } \\
\text { (lbs) divided by } \\
\text { UTS (lbs) }\end{array}$} & $\begin{array}{l}\text { Load } \\
\text { (lbs) }\end{array}$ & $\begin{array}{l}\text { UTS } \\
\text { (lbs) }\end{array}$ & $\begin{array}{l}\text { UTS } \\
(\%)\end{array}$ & $\begin{array}{l}\text { Load } \\
\text { (lbs) }\end{array}$ & $\begin{array}{l}\text { UTS } \\
\text { (lbs) }\end{array}$ & $\begin{array}{l}\text { UTS } \\
(\%)\end{array}$ & $\begin{array}{l}\text { Load } \\
\text { (lbs) }\end{array}$ & $\begin{array}{l}\text { UTS } \\
\text { (lbs) }\end{array}$ & $\begin{array}{l}\text { UTS } \\
(\%)\end{array}$ & $\begin{array}{l}\text { Load } \\
\text { (lbs) }\end{array}$ & $\begin{array}{l}\text { UTS } \\
\text { (lbs) }\end{array}$ & $\begin{array}{l}\text { UTS } \\
(\%)\end{array}$ & $\begin{array}{l}\text { Load } \\
\text { (lbs) }\end{array}$ & $\begin{array}{l}\text { UTS } \\
\text { (lbs) }\end{array}$ & $\begin{array}{l}\text { UTS } \\
(\%)\end{array}$ \\
\hline \multirow{3}{*}{ Test \# } & 1 & 3000. & 6123. & 49. & 3266. & 5867. & 56. & 3530 . & 15933. & 22. & 2800 . & 7038. & 40. & 3368 . & 7038. & 48 \\
\hline & 2 & 3000. & 6123. & 49. & 3228. & 5867. & 55. & 3353. & 15933. & 21. & 3000 . & 7038. & 43. & 3387. & 7038. & 48. \\
\hline & 3 & 3000 . & 6123. & 49. & 3438 & 5867. & 59. & - & - & - & 3000 . & 7038. & 43. & 3362. & 7038. & 48. \\
\hline
\end{tabular}


Table 5. Test matrix for test groups 1-5.

\begin{tabular}{|c|c|c|c|c|c|}
\hline $\begin{array}{l}\text { Group } \\
\#\end{array}$ & $\begin{array}{l}\text { Webbing } \\
\text { material }\end{array}$ & $\begin{array}{l}\text { Webbing } \\
\#\end{array}$ & $\begin{array}{l}\text { UTS } \\
\%\end{array}$ & $\begin{array}{l}\text { Webbing } \\
\text { length (in.) }\end{array}$ & $\begin{array}{r}\text { Start date, Date of last } \\
\text { measurement }\end{array}$ \\
\hline \multirow[t]{3}{*}{1} & \multirow[t]{3}{*}{$6 \mathrm{~K}$ Vectran } & 1 & 49 & 64 & $12 / 14 / 12,8 / 15 / 14$ \\
\hline & & 2 & 49 & 64 & $12 / 15 / 12,8 / 15 / 14$ \\
\hline & & 3 & 49 & 64 & $12 / 16 / 12,8 / 15 / 14$ \\
\hline \multirow[t]{3}{*}{2} & \multirow[t]{3}{*}{$6 \mathrm{~K}$ Vectran } & 1 & 56 & 52 & $8 / 30 / 13,8 / 15 / 14$ \\
\hline & & 2 & 55 & 52 & $11 / 23 / 13,5 / 13 / 14$ \\
\hline & & 3 & 59 & 52 & $12 / 5 / 13,8 / 15 / 14$ \\
\hline \multirow[t]{2}{*}{3} & \multirow[t]{2}{*}{$12.5 \mathrm{~K} \mathrm{Vectran}$} & 1 & 22 & 150 & $4 / 24 / 13,8 / 15 / 14$ \\
\hline & & 2 & 21 & 150 & $4 / 25 / 13,8 / 15 / 14$ \\
\hline \multirow[t]{3}{*}{4} & \multirow[t]{3}{*}{ 6K Kevlar } & 1 & 40 & 64 & $8 / 15 / 12,8 / 15 / 14$ \\
\hline & & 2 & 43 & 64 & $1 / 12 / 13,8 / 15 / 14$ \\
\hline & & 3 & 43 & 64 & $1 / 12 / 13,8 / 15 / 14$ \\
\hline \multirow[t]{3}{*}{5} & \multirow[t]{3}{*}{ 6K Kevlar } & 1 & 48 & 52 & $8 / 17 / 13,8 / 15 / 14$ \\
\hline & & 2 & 48 & 52 & $11 / 23 / 13,8 / 15 / 14$ \\
\hline & & 3 & 48 & 52 & $11 / 23 / 13,8 / 15 / 14$ \\
\hline
\end{tabular}

\section{F. Best fit curve, axes, and wave definitions}

Data from this study will be presented in graphical form. A typical graph with parameters is presented in Figure 14. The graph contains a best-fit curve relative to data, and several axes definitions. Time is presented on the horizontal axis, displacement is presented on the left vertical axis, air temperature and relative humidity are presented on the right vertical axes, and a best fit cubic polynomial curve is utilized to characterize the variation in data over time. The best-fit curve has been divided into equivalent time segments, so that statistical calculations per segment can be utilized to describe changes in data over time. A cubic polynomial curve was chosen as the best-fit curve to match a half-cycle of a sine wave.

Illustrations of four typical wave patterns are presented in Figure 15. The uniform daily wave pattern (Fig. 15a) has a constant amplitude and a repetitive 24-hour period. The distorted local wave pattern (Fig. 15b) has varying increases and decreases in slope and could have repetitive or non-repetive periods. The global wave pattern (Fig. $15 \mathrm{c}$ ) is an accumulation of all local patterns from time equals zero until the end of data collection. The annual mean wave pattern (Fig. 15d) has a one-year period and consists of the arithmetic mean of data per day over a specified number of years to be specified later in the paper.

\section{Experimental Results}

\section{A. Environmental Results}

Outside annual mean and inside air temperature data, and best-fit curves to the inside air temperature data from January 2013 through August 2014 are presented in Figure 16. Outside annual mean and inside relative humidity data, and best-fit curves to the inside humidity data from January 2013 through August 2014 are presented in Figure 17. Best-fit curves and outside annual mean data curves are graphed together to determine if the two are comparable. Data indicates that the best-fit inside air temperature curves are higher than but comparable to the outside annual mean temperature data curve, and that the best-fit inside humidity curves are lower than but comparable to the outside annual mean humidity data curve. Inside air temperature and relative humidity data were recorded over the January 2013 through August 2014 test period with a portable hygro-thermometer data logger, and outside annual mean temperature and humidity data were obtained from the nearby Langley Air Force Base (Hampton, Virginia) weather station website. The outside annual mean temperature and humidity data are the arithmetic mean of high and low temperature and humidity measurements per day over the previous twenty-five years. Variations in day-today and week-to-week inside temperature and humidity data are exhibited by distorted local wave patterns on both figures. Over the two year test period, inside temperatures decreased to a $35^{\circ} \mathrm{F}-40^{\circ} \mathrm{F}$ minimum range during the January and February time period, and increased to a $85^{\circ} \mathrm{F}-90^{\circ} \mathrm{F}$ maximum range over the June and July time period. Data indicates that variations in the range of daily temperatures remain relatively constant over the two year test period. Data indicate that variations in the range of daily humidity values increases during cooler time periods 
and decreases during warmer time periods. The gap in the temperature and humidity data between 10/1/13 and $2 / 09 / 2014$ is a period in which data was not recorded.

Tables $6 \mathrm{a}$ and $6 \mathrm{~b}$ contain statistical variance and standard deviation calculations derived from temperature data relative to the best fit curve (Fig. 16). Tables $7 \mathrm{a}$ and $7 \mathrm{~b}$ contain statistical calculations derived from humidity data relative to the best-fit curve (Fig. 17). The 2013 best-fit curves were divided into four equal segments, and the 2014 best-fit curves were divided into five equal segments to capture seasonal changes in data. Standard deviation values from Tables $6 \mathrm{a}$ and $6 \mathrm{~b}$ indicate that variations in temperature data decrease from winter to summer, and standard deviation values from Tables $7 \mathrm{a}$ and $7 \mathrm{~b}$ indicate that variations in humidity data decrease from winter to summer. The relatively high R-squared values of 0.901 and 0.958 for 2013 and 2014 temperature data, respectively, indicates a good curve fit to the data. The relatively low R-squared values of 0.15 and 0.158 for 2013 and 2014 humidity data, respectively, indicates a poor curve fit to the data. In general $\mathrm{R}$-squared data indicates that the variations in the range of day-to-day temperature data are small relative to variations in the range of the annual mean temperature data, and variations in the range of day-to-day humidity data are large relative to the range of the annual mean humidity data.

\section{B. Temperature and Humidity Effects on Creep Displacement Results}

Results from a creep study of five test groups of webbing materials evaluated with respect to temperature and humidity effects are presented in Figures 18-22. Figure 18 displays data from three 6K Vectran webbings loaded to $49 \%$ UTS from group 1, Figure 19 displays data from three 6K Vectran webbings loaded to 55\% UTS from group 2, and Figure 20 displays data from two $12.5 \mathrm{~K}$ Vectran webbings loaded to $22 \%$ UTS. Figure 21 displays data from two 6K Kevlar webbings loaded to $43 \%$ UTS, and Figure 22 displays data from three 6K Kevlar webbings loaded to $48 \%$ UTS from group 5. All figures display displacement curves, which correspond to typical primary and secondary stages of an elastic material creep displacement curve (Fig. 6). All webbings incur a large displacement during initial load application followed by a gradual increase in displacement over time. Webbings exhibit either a slight crown or a pronounced maximum displacement peak in the late January 2014 time period. All curves exhibit local wave patterns from test initiation until the date of last recorded measurements in August 2014. All local displacement wave patterns per material group appear to coincide over the test period independent of test start date. No discernible difference between Kevlar and Vectran creep displacement curves were observed. Webbing test \#1 from group 2 was halted in May 2014 due to several visible local areas of webbing damage (Fig. 23) which occurred under loading. Failure of a webbing will damage the attached displacement sensor, therefore the test was halted prior to webbing failure. All remaining test continued to generate data through the August 15, 2014 time period.

Figures 24-27 display displacement data from individual webbings with best-fit curves, and outside annual mean air temperature data. Figures 28-29 display displacement data from individual webbings and outside annual mean air temperature data. All best-fit curves were divided into three equivalent segments. Figure 24 displays data from $6 \mathrm{~K}$ Vectran webbing \#2 loaded to 49\% UTS from group 1, Figure 25 displays data from 12.5K Vectran webbing \#1 loaded to $22 \%$ from group 3, Figure 26 displays data from $6 \mathrm{~K}$ Kevlar webbing \#1 loaded to 40\% from group 4, Figure 27 displays data from 6K Kevlar webbing \#2 loaded to 43\% from group 4, Figure 28 displays data from 6K Vectran webbing \#3 loaded to 59\% from group 2, and Figure 29 displays data from 6K Kevlar webbing \#1 loaded to $48 \%$ from group 5. Figures 24-27 exhibit creep displacement curves with maximum amplitudes in late January 2014 and troughs in early July 2014 which track inversely to the outside annual mean temperature curve. The displacement curves for Vectran and Kevlar materials are an inverse of the outside annual mean temperature curve due to the negative coefficient of thermal expansion (CTE) of both webbing materials. The displacement curves are also influenced by variations in inside humidity (Fig. 17) values, however annual mean humidity variations do not display large seasonal changes, therefore the humidity effect is smaller. Data indicates that the creep displacement curves are influenced by annual environmental effects. Uniquely, data from 6K Kevlar at 40\% UTS webbing \#1 (Fig. 26) exhibits a displacement pattern with two peak amplitudes, one in late January 2013 and one in late January 2014. The January 2014 peak is higher than the January 2013 peak, indicating webbing material creep continues in conjunction with environmental effects. The test was initiated during the month of August 2012, and it is the longest-running creep test in the study. The test was initiated prior to startup of a data acquisition system, therefore a gap exists in the data between test startup in August 2012 and December 2012. Figures 28 and 29 exhibit displacement curves, which are dissimilar to the inverse of the annual mean temperature pattern. All webbings in group 2 have visible areas of material damage due to load. Webbings in group 5 do not have visible areas of material damage, however their global displacement curve patterns lack the typical decrease in displacement during warmer time periods which indicates a degree of material yielding. Data indicates that the magnitude of applied loads in groups 2 and 5 cause large deformations, and material yielding which tends to neutralize the development of a global displacement sine wave pattern, however it doesn't affect the local wave pattern. All graphs within Figs. 1822, 24-29 were generated by selecting data at 12-hour intervals, 4am and 4pm, per day from the master data file. The 
gap in the data of all figures between May 15, 2014 and June 20, 2014 is a period in which data was not recorded due to an extended power outage in the test facility.

Tables 8 through 11 contain statistical calculations of best fit curves presented in Figures 24, 25, 26, and 27 respectively. All best fit curves consist of three equivalent time period segments. Data indicate that standard deviation values increase from summer to winter indicating the spread in displacement data increases from summer to winter. All R-squared values are 0.9 or above indicating good fit between displacement data and best-fit cubic polynomial curves.

\section{Local Temperature and Humidity Effects on Creep Displacement Results}

Figures 30, 31, and 32 display inside temperature and humidity data, and displacement data from $6 \mathrm{~K}$ Kevlar webbing \#1 group 4 (Fig. 24), over three distinct seasonal time periods to highlight the effect of temperature and humidity on local creep displacement behavior. The specified test was selected because it is the longest running test and therefore a large amount of data exist for study. The material was selected because experimental data has shown little discernible difference between environmental effects on Kevlar and Vectran webbing materials. All figures have the same range on the right and left vertical axes, however the left vertical axis translates up or down to encompass displacement data. The axis range restraint will help highlight temperature and humidity effects on displacement data.

Figure 30 presents data from the summer time period of July 2014. Temperature data exhibit a wave pattern with a range of approximately $7{ }^{\circ} \mathrm{F}$ and repetitive periods. Humidity data exhibits a wave pattern with several distortions, a range of $15 \%$, and repetitive periods. The displacement curve exhibits a wave pattern with several distortions, a range of 0.02 inches, and repetitive periods. An inverse relationship between a mean temperature curve and a best-fit displacement curve was shown in Figures 24-27, however an inverse relationship between the temperature curve and the displacement curve in Figure 30 is not noticeable, which maybe due to the influence of the humidity.

Figure 31 presents data from the spring time period of March to April 2013. Temperature data exhibit a distorted wave pattern with a range of $25^{\circ} \mathrm{F}$ and repetitive periods. Humidity data exhibit a distorted wave pattern with a range of $35 \%$ and non-repetitive periods. Data indicate that as temperatures decrease humidity values increase over a larger range and non-repetitive time periods. The displacement curve exhibits a distorted wave pattern with a range of .05 inches and non-repetitive periods. The graph exhibits an inverse relationship between the temperature and humidity curves and the displacement curve. Data indicate that the webbing material has negative CTE and CHE values.

Figure 32 presents data from the winter time period of February 2014. Temperature data exhibit a distorted wave pattern with a range of $25^{\circ} \mathrm{F}$ and repetitive periods. Humidity data exhibits a distorted wave pattern with a range of $50 \%$ and non-repetitive periods. The displacement curve exhibits a distorted wave pattern with a range of .08 inches and non-repetitive periods. The graph exhibits an inverse relationship between the temperature and humidity curves and displacement curve.

Overall, test data indicates several effects of environmental conditions on local creep displacement data over the three time periods. First, as temperatures decrease, humidity values vary over a larger range and non-repetitive time periods. Second, as temperatures decrease, an inverse relationship of temperature and humidity data to displacement data is more quantifiable (Fig. 30-32). Third, standard deviation values from humidity Tables 7a-b increase from summer to winter more than standard deviation values from temperature Tables 6a-b. All factors indicate that variations in humidity values over day-to-day periods have a significant influence on local webbing displacement behavior. Note, however that in extremely hot time periods humidity and temperature may contribute equally to displacement values.

\section{Conclusion}

A two year study of environmental effects on the creep behavior of five groups of high strength Kevlar and Vectran webbings has been presented. Webbings in each group had the same length, load rating, applied load, and test period. Results were generated from a custom designed full-scale creep test apparatus consisting of I-beam structures, concrete weights, suspended webbings, and displacement transducer sensors. The creep test apparatus was assembled within a high bay test facilty without environmental HVAC controls. Inside air temperature and relative humidity values were recorded within the test facility during the test period.

Results show that all webbing groups exhibit the initial two stages of a typical creep curve for an elastic material. Results also show that all webbings exhibit unique local wave patterns over the duration of the test period. Data indicate that the local pattern is primarily generated by daily variations in relative humidity values within the test facility. Data indicate that after a three to six month period, where webbings reach a steady-state creep condition, an 
annual sinusoidal displacement pattern is exhibited, primarily due to variations in annual mean temperature values. Data indicates that variations in daily temperature values and annual mean humidity values have limited secondary effects on creep displacement behavior. Results show that webbings in groups 2 and 5 do not exhibit well defined annual sinusoidal displacement patterns because the magnitude of the applied loads cause large deformations and material yielding which tends to neutralize the annual sinusoidal displacement pattern. Data indicate that the webbing material has negative CTE and CHE values, and no discernible differences were observed between environmental effects on the creep behavior of Kevlar and Vectran webbings.

Overall, results indicate that environmental conditions effect the creep behavior of Kevlar and Vectran webbings from test initiation until material failure. The study indicates that definition of applied load, environmental conditions, mechanical strength, coefficient of thermal expansion, and hygroscopic properties of webbings are fundamental requirements for quantifying accurate creep behavior over multiple years. Currently proposed long duration space exploration missions to destinations such as near Earth asteroids, Mars, and the Moon may require lightweight inflatable structures. Knowledge of environmental effects on the creep behavior of high strength webbings is essential to enable these exploration missions.

\section{Acknowledgments}

Authors wishes to thank, "Structural Mechanics \& Concepts" Branch Head, David Brewer. Authors would also like to thank Joseph G. Sikora, Dr. Mark J. Shuart, Sherry Monk, Dr. Sandra Walker, James Phelps, Martin J. McKenney, Thomas W. Jones, and Harriett Dismond. Assistance provided by personnel in the Materials Experiment Branch, Structures Experiments Branch, Aerospace Composite Model Development Section, and Structures Testing Branch was also appreciated. Finally, the primary author would like to thank his parents for their love and support.

\section{References}

${ }^{1}$ DelaFuente Horacio, Raboin, Jasen L, Spexarth, Gary R., and Valle, Gerard D., (2000) TransHab: NASA's Large-Scale Inflatable Spacecraft. AIAA-2000-1822, AIAA Space Inflatables Forum, Atlanta (Georgia), April 3-6.

${ }^{2}$ Jones, Thomas C., Doggett, William R., Stanfield, Clarence E., “Accelerated Creep Testing of High Strength Aramid Webbing," AIAA Paper 2012-1771, NF1676L-13173, 53rd AIAA/ASME/ASCE/AHS/ASC Structures, Structural Dynamics and Materials Conference; 23-26 Apr. 2012; Honolulu, HI; United States.

${ }^{3}$ Lichodziejewski, D., Kelley, C., Tutt, B., Brown, G., "Design and Testing of the Inflatable Aeroshell for the IRVE-3 Flight Experiment," AIAA Paper 2012-1771, NF1676L-13173, 53rd AIAA/ASME/ASCE/AHS/ASC Structures, Structural Dynamics and Materials Conference; 23-26 Apr. 2012; Honolulu, HI; United States.

${ }^{4}$ Cavallaro, Paul V., Johnson, Matthew E., Sadegh, Ali M., "Mechanics of Plain-Woven Fabrics for Inflatable Structures," Symposium on Design and Manufacturing of Composites, Composite Structures, Volume 61, Issue 4, September 2003, Pages 375-393.

${ }^{5}$ Lin, John K. H., Sapna III, George H., Cadogan, David P., Scarborough, Stephen E., "Inflatable Rigidizable Isogrid Boom Development,", AIAA 2002-1297, 43 ${ }^{\text {rd }}$ AIAA/ASME/ASCE/AHS/ASC Structures, Structural Dynamics, and Materials Conference \& Exhibit AIAA Gossamer Spacecraft Forum, April 22-25, 2002, Denver, CO.

${ }^{6}$ Findley, William N., Lai, James S., Onaran, Kasif, Creep and Relaxation of Nonlinear Viscoelastic Materials. Copyright 1976, North-Holland Publishing Company.

7Jones, Thomas C., Doggett, William R., "Time-Dependent Behavior of High-Strength Kevlar and Vectran Webbings", 55th AIAA/ASME/ASCE/AHS/ASC Structures, Structural Dynamics, and Materials Conference, January 13-17, 2014, National Harbor, Maryland.

\footnotetext{
${ }^{8}$ Kenner, Winfred S., Jones, Thomas C., Doggett, William R., "Long Term Displacement Data of Woven Fabric Webbings under Constant Load for Inflatable Structures", 55th AIAA/ASME/ASCE/AHS/ASC Structures, Structural Dynamics, and Materials Conference, January 13-17, 2014, National Harbor, Maryland.
} 


\begin{tabular}{|c|c|c|c|c|c|}
\hline \multirow[t]{2}{*}{ Year } & \multirow{2}{*}{$\begin{array}{l}\text { Statistical } \\
\text { calculation }\end{array}$} & \multicolumn{4}{|c|}{ Numerical values per segment (time period) } \\
\hline & & $\begin{array}{l}\text { Segment } 1 \text { - winter } \\
(1 / 24 / 13-3 / 15 / 13)\end{array}$ & $\begin{array}{l}\text { Segment } 2 \text { - spring } \\
(3 / 15 / 13-5 / 4 / 13)\end{array}$ & $\begin{array}{l}\text { Segment } 3 \text { - spring } \\
(5 / 4 / 13-6 / 23 / 13)\end{array}$ & $\begin{array}{l}\text { Segment } 4 \text { - summer } \\
(6 / 23 / 13-8 / 11 / 13)\end{array}$ \\
\hline \multirow[t]{3}{*}{2013} & Variance & 20.698076 & 33.56348 & 12.14323 & 8.29572 \\
\hline & $\begin{array}{l}\text { Standard } \\
\text { Deviation }\end{array}$ & 4.54951387 & 5.793399 & 3.484714 & 2.88022 \\
\hline & $\begin{array}{l}\text { Best fit cubic } \\
\text { polynomial and } \mathrm{R} 2\end{array}$ & \multicolumn{4}{|c|}{$\begin{array}{l}Y(x)=\left(-1.0176 \times 10^{-6}\right) \times x^{3}+\left(5.233 \times 10^{-4}\right) \times x^{2}+\left(5.481 \times 10^{-2}\right) \times x+42.6284 \\
R 2=.901099\end{array}$} \\
\hline
\end{tabular}

Table 6a. Statistical calculations of temperature data within the test facility in 2013.

\begin{tabular}{|c|l|c|c|c|c|c|}
\hline \multirow{2}{*}{ Year } & $\begin{array}{l}\text { Statistical } \\
\text { calculation }\end{array}$ & \multicolumn{5}{|c|}{ Numerical values per segment (time period) } \\
\cline { 2 - 7 } & $\begin{array}{l}\text { Segment 1 - winter } \\
(1 / 24 / 14-2 / 27 / 14)\end{array}$ & $\begin{array}{l}\text { Segment 2 - spring } \\
(2 / 27 / 14-4 / 3 / 14)\end{array}$ & $\begin{array}{l}\text { Segment 3 - spring } \\
(4 / 3 / 14-5 / 10 / 14)\end{array}$ & $\begin{array}{l}\text { Segment 4 - spring } \\
(5 / 10 / 14-6 / 13 / 14)\end{array}$ & $\begin{array}{l}\text { Segment 5 - summer } \\
(6 / 13 / 14-7 / 18 / 14)\end{array}$ \\
\hline \multirow{2}{*}{2014} & Variance & 16.6018877 & 14.205825 & 8.75391 & 10.527145 & 5.13995 \\
\cline { 2 - 6 } & $\begin{array}{l}\text { Standard } \\
\text { Deviation }\end{array}$ & 4.0745414 & 3.769062 & 2.9587 & 3.244556 & 2.267147 \\
\cline { 2 - 6 } & $\begin{array}{l}\text { Best fit cubic } \\
\text { polynomial and R2 }\end{array}$ & \multicolumn{2}{|c|}{$\begin{array}{l}\mathrm{Y}(\mathrm{x})=\left(-6.7057 \times 10^{-13}\right) \times \mathrm{x}^{3}+\left(4.7746 \times 10^{-8}\right) \times \mathrm{x}^{2}+\left(1.398 \times 10^{-5}\right) \times \mathrm{x}+40.284 \\
\mathrm{R} 2=.957931\end{array}$} \\
\hline
\end{tabular}

Table 6b. Statistical calculations of temperature data within the test facility in 2014 .

\begin{tabular}{|c|l|c|c|c|c|}
\hline \multirow{2}{*}{ Year } & \multirow{2}{*}{$\begin{array}{l}\text { Statistical } \\
\text { calculation }\end{array}$} & $\begin{array}{l}\text { Segment 1 - winter } \\
(1 / 24 / 13-3 / 15 / 13)\end{array}$ & $\begin{array}{l}\text { Segment 2 - spring } \\
(3 / 15 / 13-5 / 4 / 13)\end{array}$ & $\begin{array}{c}\text { Segment 3 - spring } \\
(5 / 4 / 13-6 / 23 / 13)\end{array}$ & $\begin{array}{l}\text { Segment 4 - summer } \\
(6 / 23 / 13-8 / 11 / 13)\end{array}$ \\
\cline { 2 - 6 } 2013 & Variance & 162.32999 & 99.677074 & 67.99308 & 25.36655 \\
\cline { 2 - 5 } & $\begin{array}{l}\text { Standard } \\
\text { Deviation }\end{array}$ & 12.740878 & 9.9838406 & 8.24579 & 5.036522 \\
\cline { 2 - 5 } & $\begin{array}{l}\text { Best fit cubic } \\
\text { polynomial and R2 }\end{array}$ & \multicolumn{2}{|c|}{$\begin{array}{l}\mathrm{Y}(\mathrm{x})=\left(-5.454 \times 10^{-7}\right) \times \mathrm{x}^{3}+\left(3.233 \times 10^{-4}\right) \times \mathrm{x}^{2}+\left(-1.511 \times 10^{-2}\right) \times \mathrm{x}+57.8 \\
\mathrm{R} 2=.150018\end{array}$} \\
\hline
\end{tabular}

Table 7a. Statistical calculations of humidity data within the test facility in 2013.

\begin{tabular}{|c|l|c|c|c|c|c|}
\hline Year & $\begin{array}{l}\text { Statistical } \\
\text { calculation }\end{array}$ & \multicolumn{5}{|c|}{ Numerical values per segment (time period) } \\
\cline { 3 - 7 } & $\begin{array}{l}\text { Segment 1 - winter } \\
(1 / 24 / 14-2 / 27 / 14)\end{array}$ & $\begin{array}{c}\text { Segment 2 - spring } \\
(2 / 27 / 14-4 / 3 / 14)\end{array}$ & $\begin{array}{c}\text { Segment 3 - spring } \\
(4 / 3 / 14-5 / 10 / 14)\end{array}$ & $\begin{array}{c}\text { Segment 4 - spring } \\
(5 / 10 / 14-6 / 13 / 14)\end{array}$ & $\begin{array}{c}\text { Segment 5 - summer } \\
(6 / 23 / 14-7 / 18 / 14)\end{array}$ \\
\hline \multirow{2}{*}{2014} & Variance & 156.241798 & 159.270555 & 74.736155 & 44.962907 & 27.747579 \\
\cline { 2 - 6 } & $\begin{array}{l}\text { Standard } \\
\text { Deviation }\end{array}$ & 12.4996719 & 12.620244 & 8.6450075 & 6.7054386 & 5.267597 \\
\cline { 2 - 7 } & $\begin{array}{l}\text { Best fit cubic } \\
\text { polynomial and R2 }\end{array}$ & \multicolumn{2}{|c|}{$\begin{array}{l}\mathrm{Y}(\mathrm{x})=\left(3.339 \times 10^{-13}\right) \times \mathrm{x}^{3}+\left(-3.548 \times 10^{-8}\right) \times \mathrm{x}^{2}+\left(1.2505 \times 10^{-3}\right) \times \mathrm{x}+48.8886 \\
\mathrm{R} 2=.15828\end{array}$} \\
\hline
\end{tabular}

Table 7b. Statistical calculations of humidity data within the test facility in 2014.

10

American Institute of Aeronautics and Astronautics 


\begin{tabular}{|c|c|c|c|c|}
\hline \multirow{2}{*}{$\begin{array}{l}\text { Webbing } \\
\text { material }\end{array}$} & \multirow{2}{*}{$\begin{array}{l}\text { Statistical } \\
\text { calculation }\end{array}$} & \multicolumn{3}{|c|}{ Numerical values per segment (time period) } \\
\hline & & $\begin{array}{l}\text { Segment } 1 \text { - summer } \\
(6 / 11 / 13-9 / 20 / 13)\end{array}$ & $\begin{array}{l}\text { Segment } 2 \text { - fall } \\
(9 / 20 / 13-12 / 15 / 13)\end{array}$ & $\begin{array}{l}\text { Segment } 3 \text { - winter } \\
(12 / 15 / 13-3 / 15 / 14)\end{array}$ \\
\hline \multirow{3}{*}{$\begin{array}{l}6 \mathrm{~K} \\
\text { Vectran }\end{array}$} & Variance & $2.93225 \times 10^{-5}$ & $5.5808 \times 10^{-5}$ & $1.0525 \times 10^{-4}$ \\
\hline & $\begin{array}{l}\text { Standard } \\
\text { Deviation }\end{array}$ & .00541501 & .00747048 & .010259 \\
\hline & $\begin{array}{l}\text { Best fit cubic } \\
\text { polynomial and } \mathrm{R} 2\end{array}$ & \multicolumn{3}{|c|}{$\begin{array}{l}Y(x)=\left(-2.04289 \times 10^{-9}\right) \times x^{3}+\left(1.34 \times 10^{-6}\right) \times x^{2}+\left(1.5923 \times 10^{-5}\right) \times x+.40752 \\
R 2=.946637\end{array}$} \\
\hline
\end{tabular}

Table 8. Statistical calculations of displacement data of $6 \mathrm{~K}$ Vectran webbing \#2 group 1 loaded to $49 \%$ UTS.

\begin{tabular}{|c|c|c|c|c|}
\hline \multirow{2}{*}{$\begin{array}{l}\text { Webbing } \\
\text { material }\end{array}$} & \multirow{2}{*}{$\begin{array}{l}\text { Statistical } \\
\text { calculation }\end{array}$} & \multicolumn{3}{|c|}{ Numerical values per segment (time period) } \\
\hline & & $\begin{array}{l}\text { Segment } 1 \text { - summer } \\
(6 / 11 / 13-9 / 20 / 13)\end{array}$ & $\begin{array}{c}\text { Segment } 2 \text { - fall } \\
(9 / 20 / 13-12 / 15 / 13)\end{array}$ & $\begin{array}{l}\text { Segment } 3 \text { - winter } \\
(12 / 15 / 13-3 / 15 / 14)\end{array}$ \\
\hline \multirow{3}{*}{$\begin{array}{l}12.5 \mathrm{~K} \\
\text { Vectran }\end{array}$} & Variance & $4.51169 \times 10^{-5}$ & $7.59708 \times 10^{-5}$ & $9.3707 \times 10^{-5}$ \\
\hline & \begin{tabular}{|l|} 
Standard \\
Deviation \\
\end{tabular} & .00671691 & .00871613 & .00968024 \\
\hline & $\begin{array}{l}\text { Best fit cubic } \\
\text { polynomial and } \mathrm{R} 2\end{array}$ & \multicolumn{3}{|c|}{$\begin{array}{l}\mathrm{Y}(\mathrm{x})=\left(-1.369 \times 10^{-9}\right) \times \mathrm{x}^{3}+\left(8.0237 \times 10^{-7}\right) \times \mathrm{x}^{2}+\left(1.182 \times 10^{-4}\right) \times \mathrm{x}+.38489 \\
\mathrm{R} 2=.944445\end{array}$} \\
\hline
\end{tabular}

Table 9. Statistical calculations of displacement data of $12.5 \mathrm{~K}$ Vectran webbing \#1 group 3 loaded to $22 \%$ UTS.

\begin{tabular}{|c|c|c|c|c|}
\hline \multirow{2}{*}{$\begin{array}{l}\text { Webbing } \\
\text { material }\end{array}$} & \multirow{2}{*}{$\begin{array}{l}\text { Statistical } \\
\text { calculation }\end{array}$} & \multicolumn{3}{|c|}{ Numerical values per segment (time period) } \\
\hline & & $\begin{array}{l}\text { Segment } 1 \text { - summer } \\
(6 / 11 / 13-9 / 20 / 13)\end{array}$ & $\begin{array}{l}\text { Segment } 2 \text { - fall } \\
(9 / 20 / 13-12 / 15 / 13)\end{array}$ & $\begin{array}{l}\text { Segment } 3 \text { - winter } \\
(12 / 15 / 13-3 / 15 / 14)\end{array}$ \\
\hline \multirow{3}{*}{$\begin{array}{l}6 \mathrm{~K} \\
\text { Kevlar }\end{array}$} & Variance & $3.33956 \times 10^{-5}$ & $1.12188 \times 10^{-4}$ & $1.6735 \times 10^{-4}$ \\
\hline & $\begin{array}{l}\text { Standard } \\
\text { Deviation }\end{array}$ & .0057789 & .01059189 & .01293655 \\
\hline & $\begin{array}{l}\text { Best fit cubic } \\
\text { polynomial and R2 }\end{array}$ & \multicolumn{3}{|c|}{$\begin{array}{l}Y(x)=\left(-1.3563 \times 10^{-9}\right) \times x^{3}+\left(7.9679 \times 10^{-7}\right) \times x^{2}+\left(1.34 \times 10^{-4}\right) \times x+.31867 \\
R 2=.916808\end{array}$} \\
\hline
\end{tabular}

Table 10. Statistical calculations of displacement data of 6K Kevlar webbing \#1 group 4 loaded to $40 \%$ UTS.

\begin{tabular}{|c|c|c|c|c|}
\hline \multirow{2}{*}{$\begin{array}{l}\text { Webbing } \\
\text { material }\end{array}$} & \multirow{2}{*}{$\begin{array}{l}\text { Statistical } \\
\text { calculation }\end{array}$} & \multicolumn{3}{|c|}{ Numerical values per segment (time period) } \\
\hline & & $\begin{array}{l}\text { Segment } 1 \text { - summer } \\
(6 / 11 / 13-9 / 20 / 13)\end{array}$ & $\begin{array}{l}\text { Segment } 2 \text { - fall } \\
(9 / 20 / 13-12 / 15 / 13)\end{array}$ & $\begin{array}{l}\text { Segment } 3 \text { - winter } \\
(12 / 15 / 13-3 / 15 / 14)\end{array}$ \\
\hline \multirow{3}{*}{$\begin{array}{l}6 \mathrm{~K} \\
\text { Kevlar }\end{array}$} & Variance & $3.94368 \times 10^{-5}$ & $1.60545 \times 10^{-4}$ & $1.83717 \times 10^{-4}$ \\
\hline & $\begin{array}{l}\text { Standard } \\
\text { Deviation }\end{array}$ & .00627987 & .01267 & .013554 \\
\hline & $\begin{array}{l}\text { Best fit cubic } \\
\text { polynomial and R2 }\end{array}$ & \multicolumn{3}{|c|}{$\begin{array}{l}Y(x)=\left(-2.346 \times 10^{-9}\right) \times x^{3}+\left(1.6957 \times 10^{-0}\right) \times x^{2}+\left(-8.048 \times 10^{-9}\right) \times x+4.28058 \\
R 2=.909856\end{array}$} \\
\hline
\end{tabular}

Table 11. Statistical calculations of displacement data of 6K Kevlar webbing \#2 group 4 loaded to $43 \%$ UTS. 


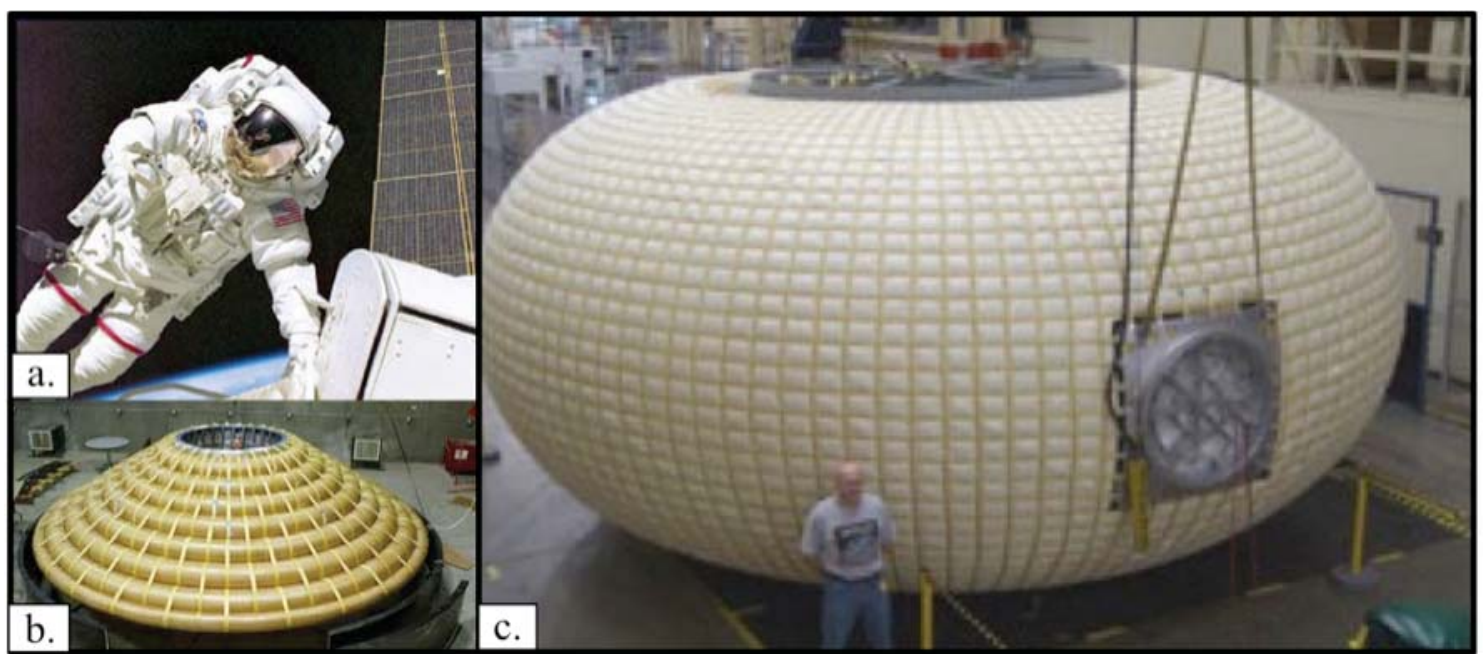

Figure 1. Examples of inflatable structures, a.) astronaut extra-vehicular activity (EVA) suit, b.) Inflatable aeroshell, and c.) Inflatable habitat with torus geometry.

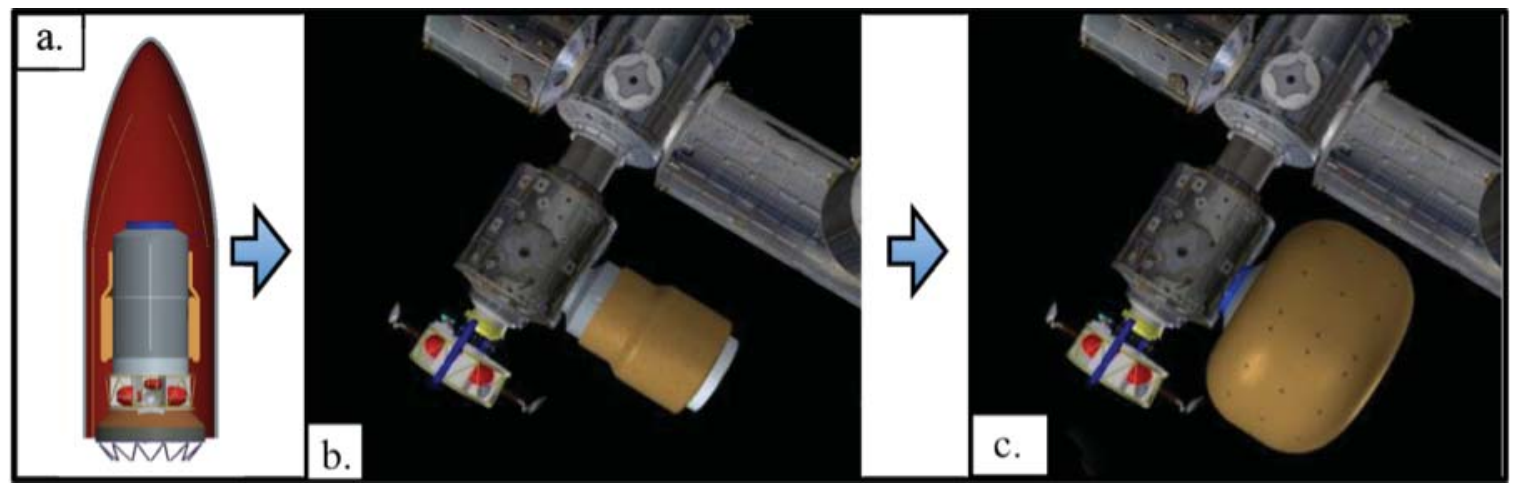

Figure 2. Conceptual vision of inflatable structure from payload to operational module, a.) payload, b.) attached to space station, and c.) deployed and operational.

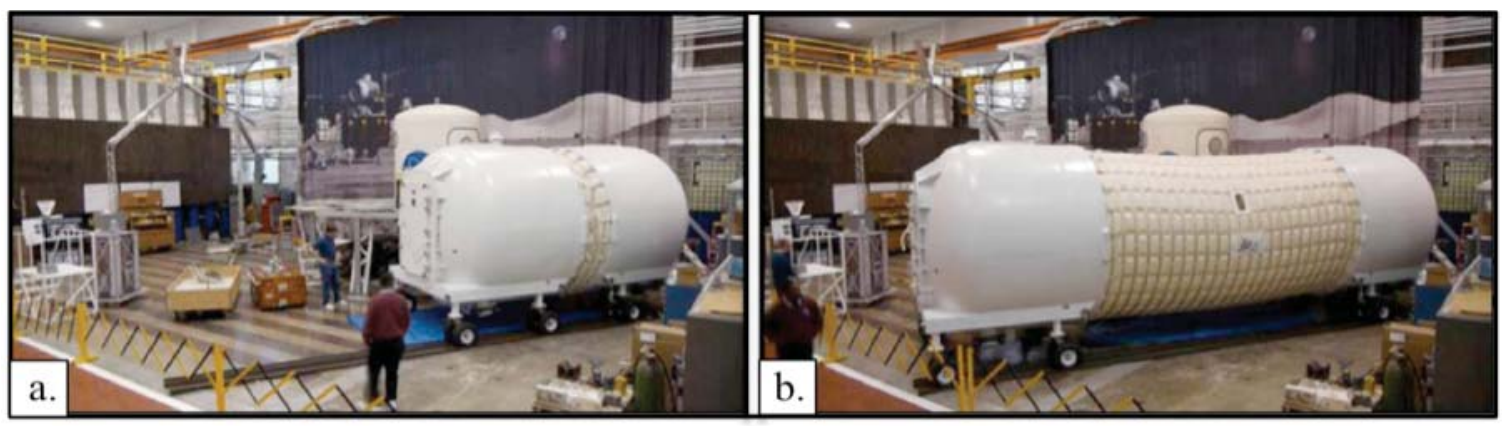

Figure 3. Demonstration of deployment of an expandable technology demonstrator structures designed for Lunar or Mars surface applications. 


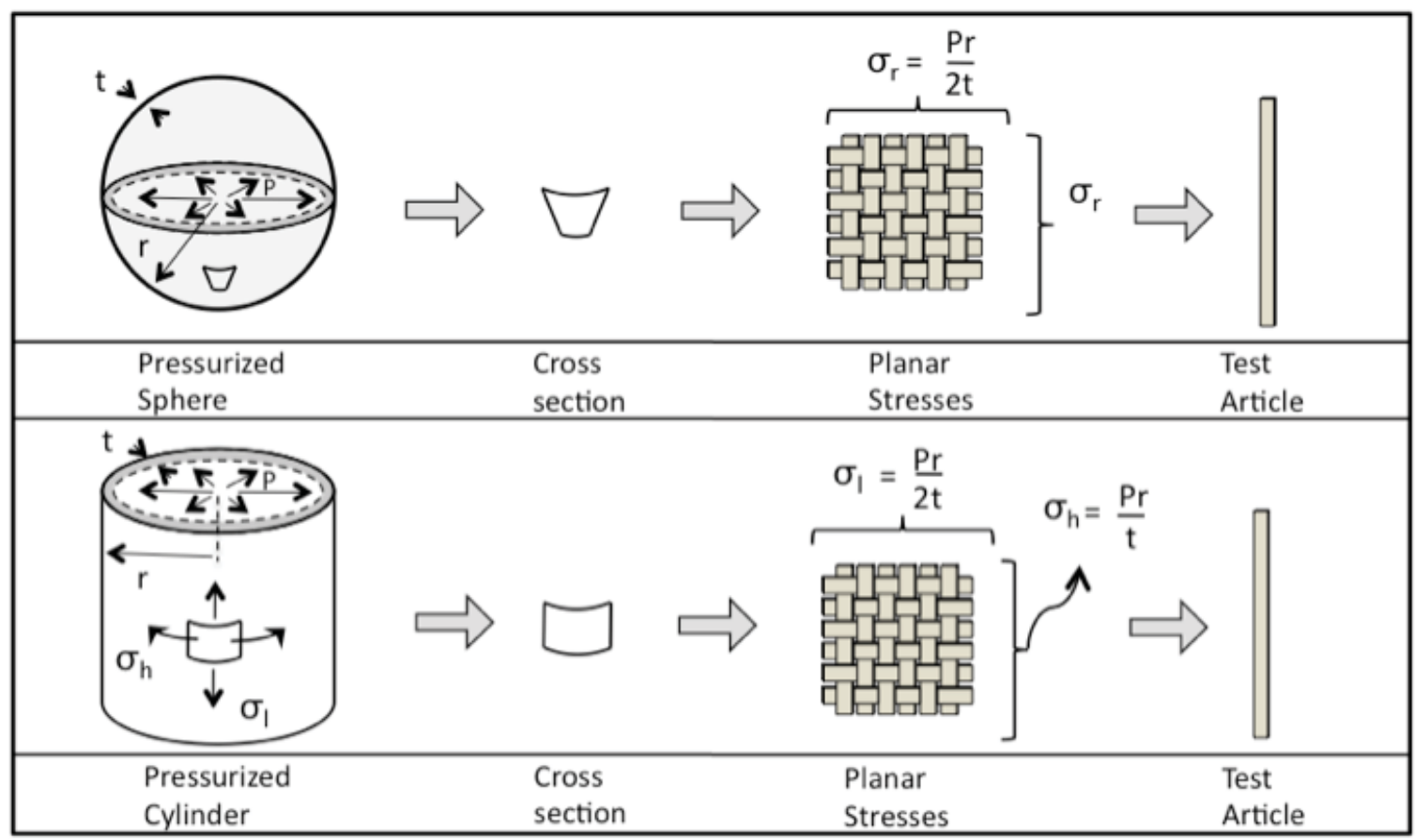

Figure 4. Basic pressure vessel equations and load effect on webbing.

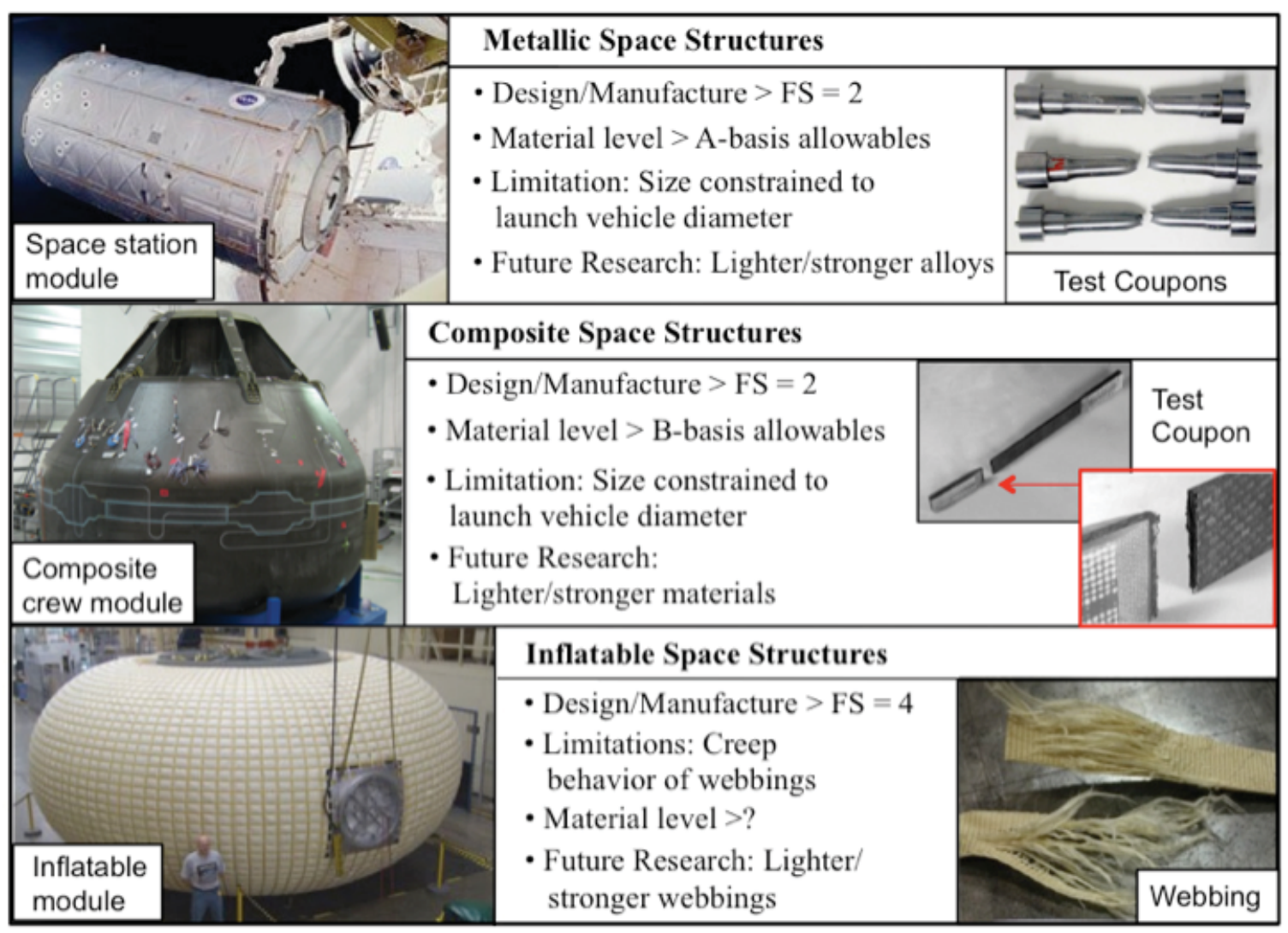

Figure 5. Aerospace materials database review. 


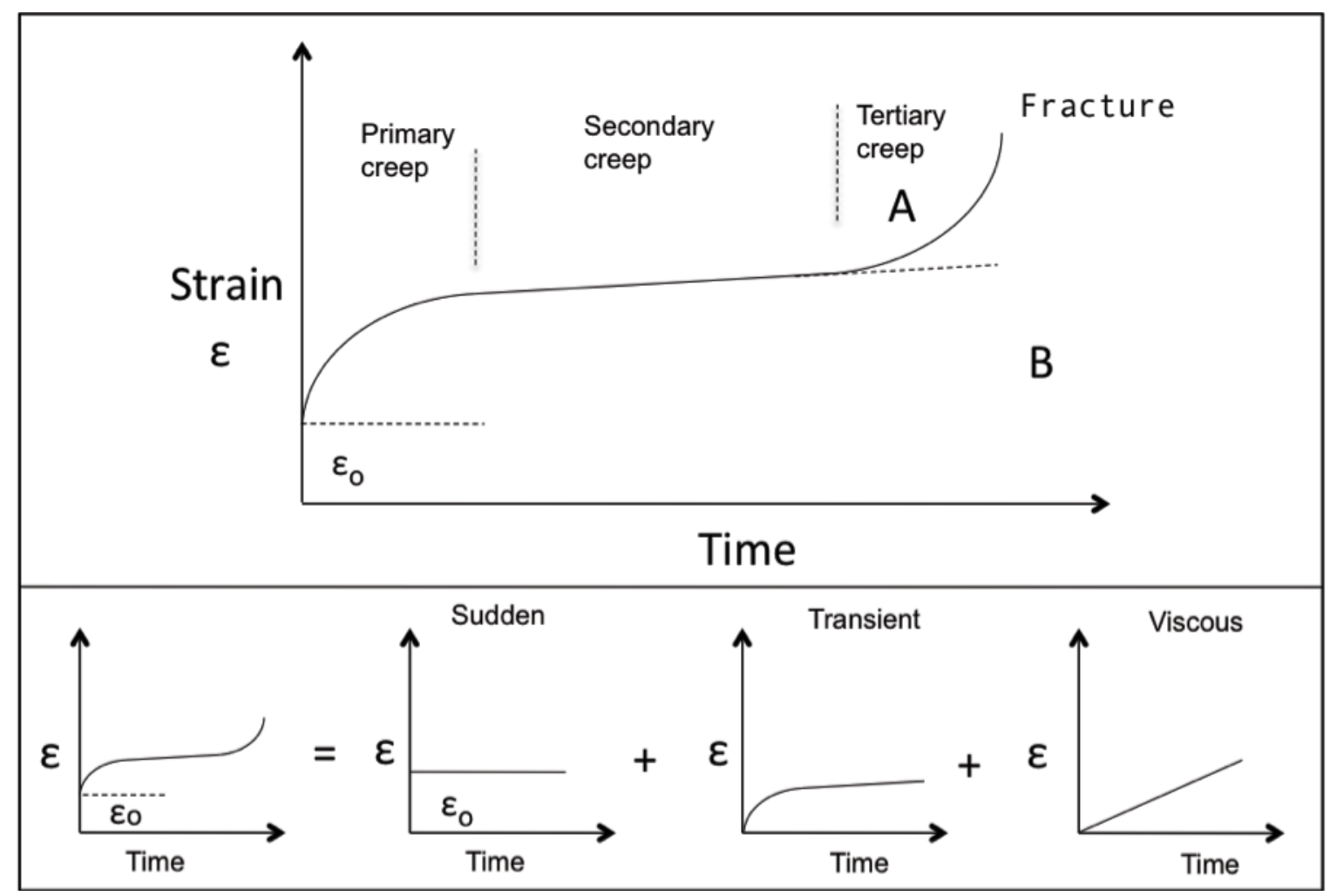

Figure 6. Three stages of a creep curve.

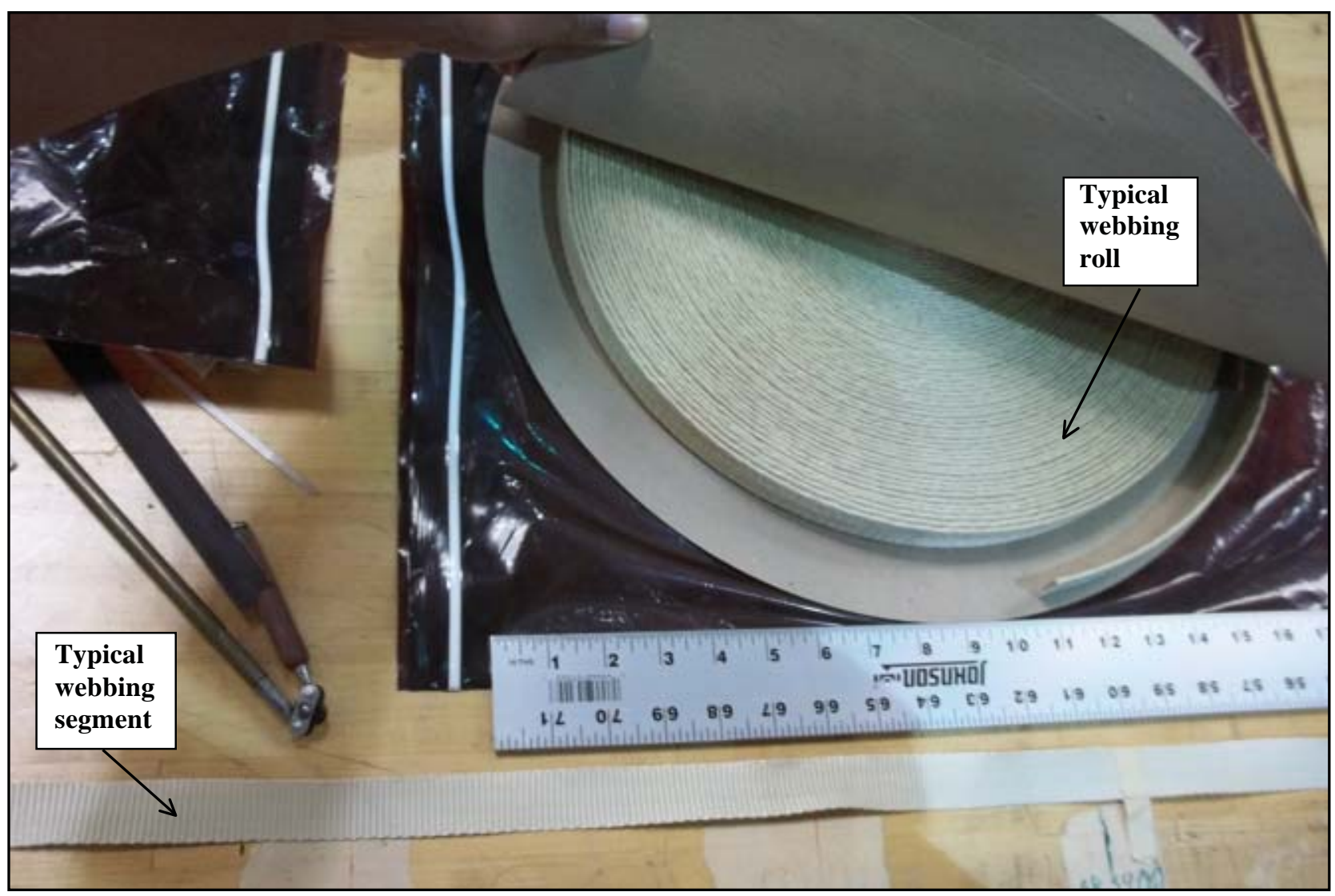

Figure 7. Typical roll and segment of Vectran webbing. 


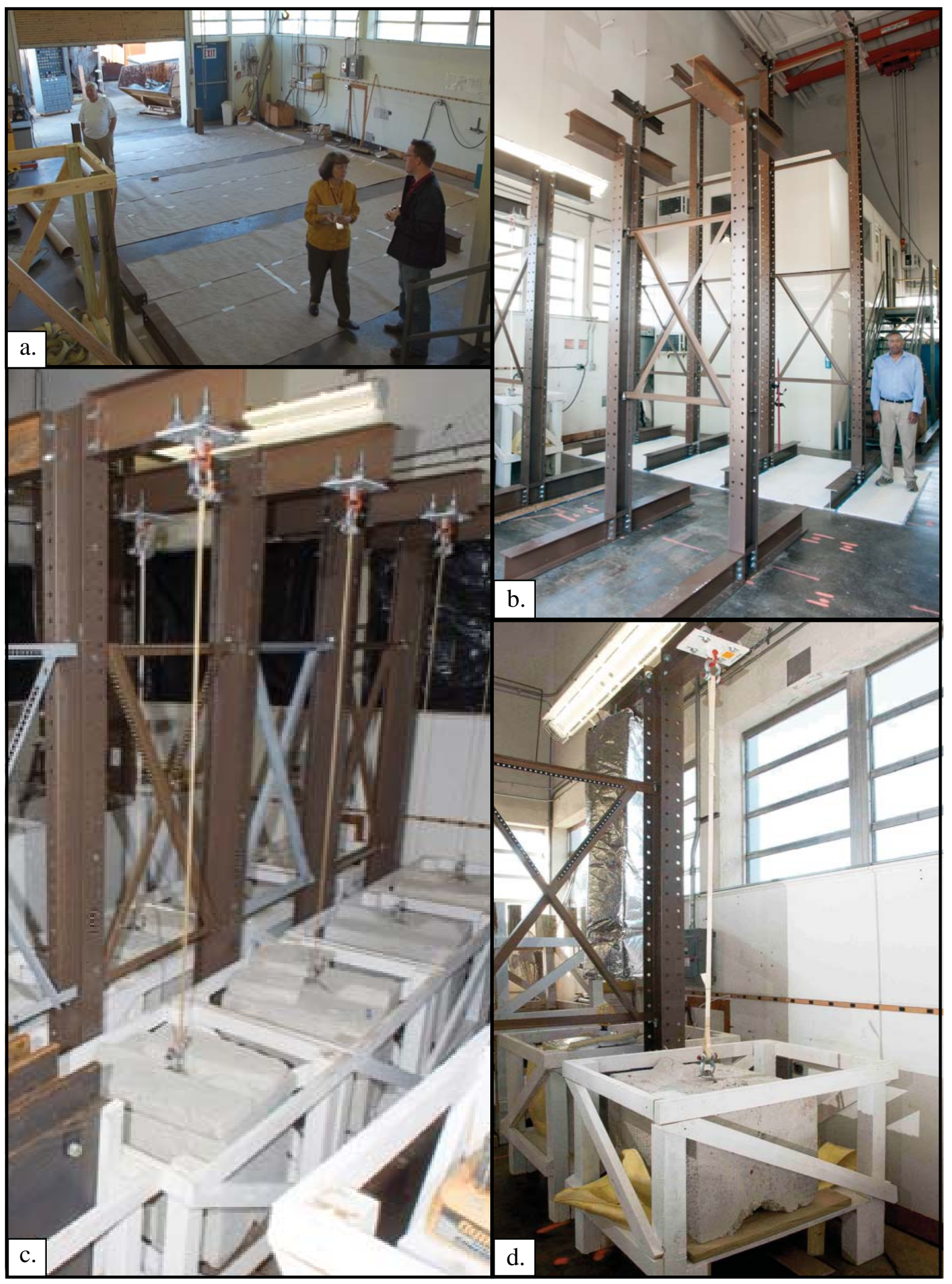

Figure 8. Test facility build: a.) empty facility, b.) two rows of double cantilevered I-beam structure, c.) row one of Kevlar \& Vectran creep tests, d.) typical creep test. 


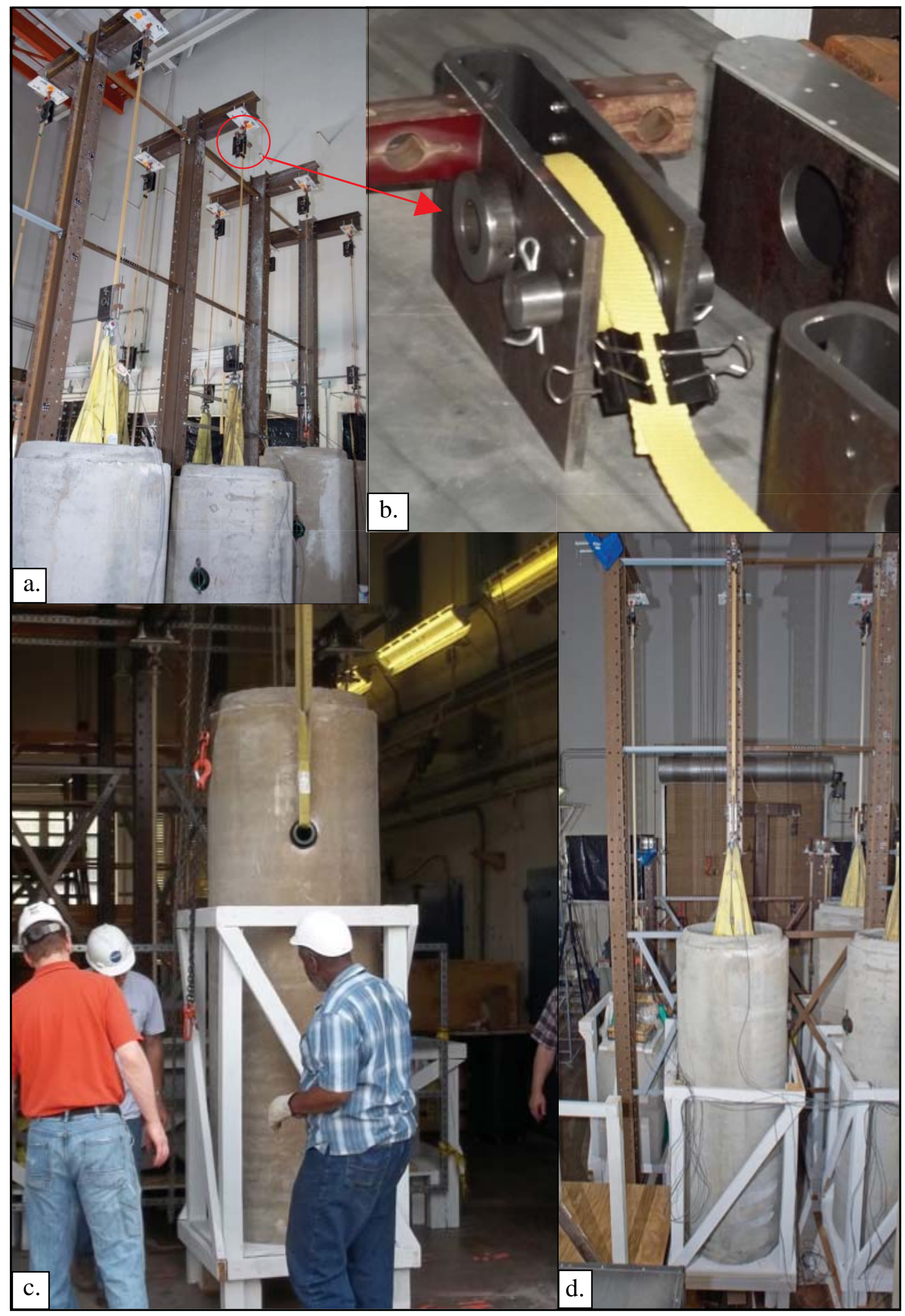

Figure 9. Hardware for second row of creep tests; a.) four Kevlar tests, b.) custom restraint fixture with webbing, c.) concrete culvert weight, d.) typical creep test. 


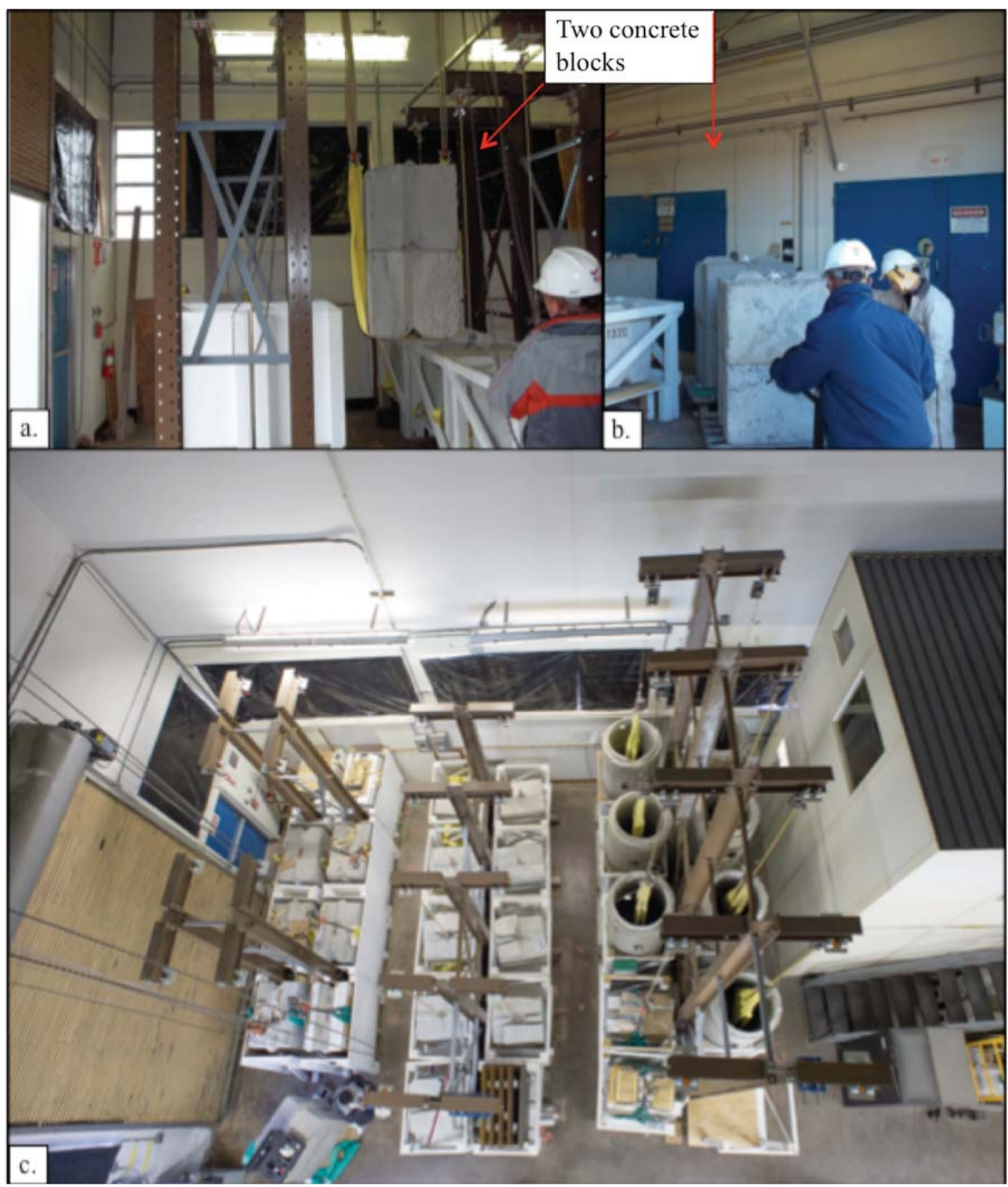

Figure 10. Hardware for third row of creep tests and top view of test site; a.) two concrete block weights being lifted into containment structure, $b$.) positoning of two concrete blocks with pallet jack, c.) top view of fully populated and operational creep test facility. 


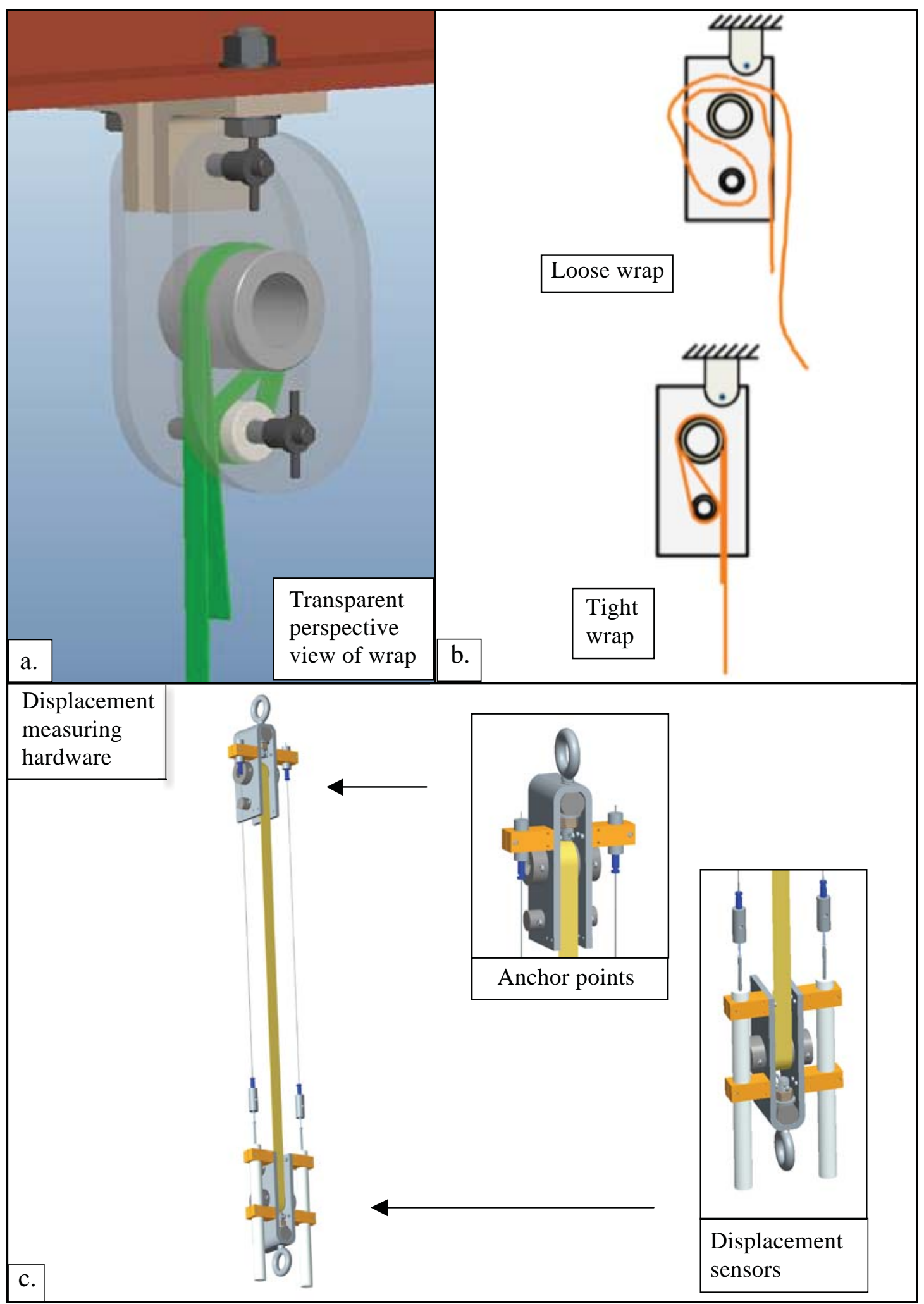

Figure 11. Webbing restraint fixture hardware and displacement sensors; a.) image of restraint hardware with two transducer sensors, b.) tranparent perspective view of wrap, and c.) side view of wrap. 


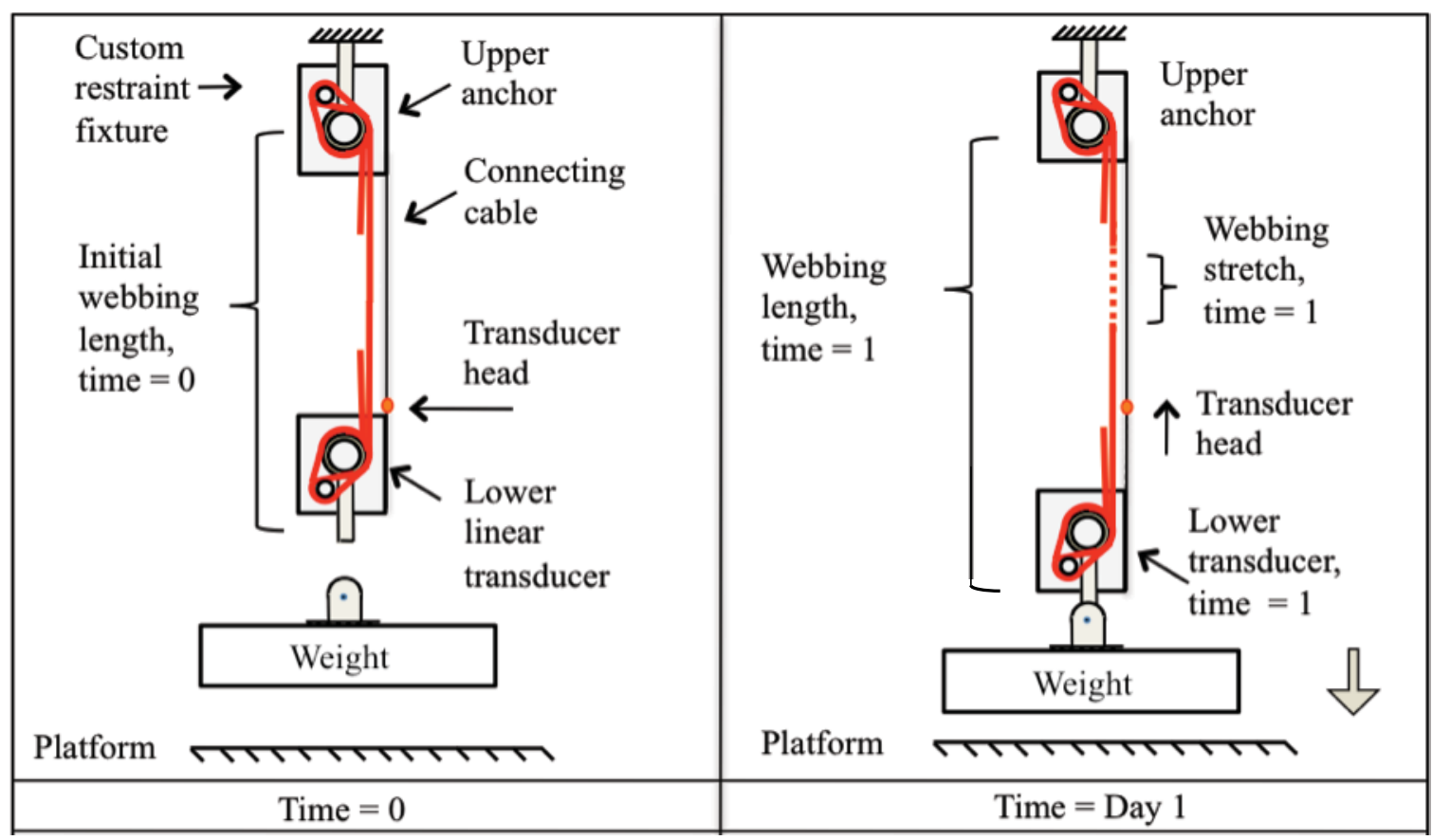

Figure 12. Overview of hardware and how linear transducer method is utilized to acquire webbing displacements over time.

\begin{tabular}{|l|c|c|c|}
\hline \multicolumn{5}{|c|}{ Longitudinal 1-D Mechanical Wave Motion } \\
\hline Start time = Day 1 & Time = Day 12 & Time = Day 20 & Time = Day 55 \\
\hline & & & \\
\hline Weight & Weight & Temperature 20 & Temperature 55 \\
& Humidity & Humidity & \\
\hline
\end{tabular}

Figure 13. Mechanical wave motion of webbing material due to varying temperature and humidity values. 


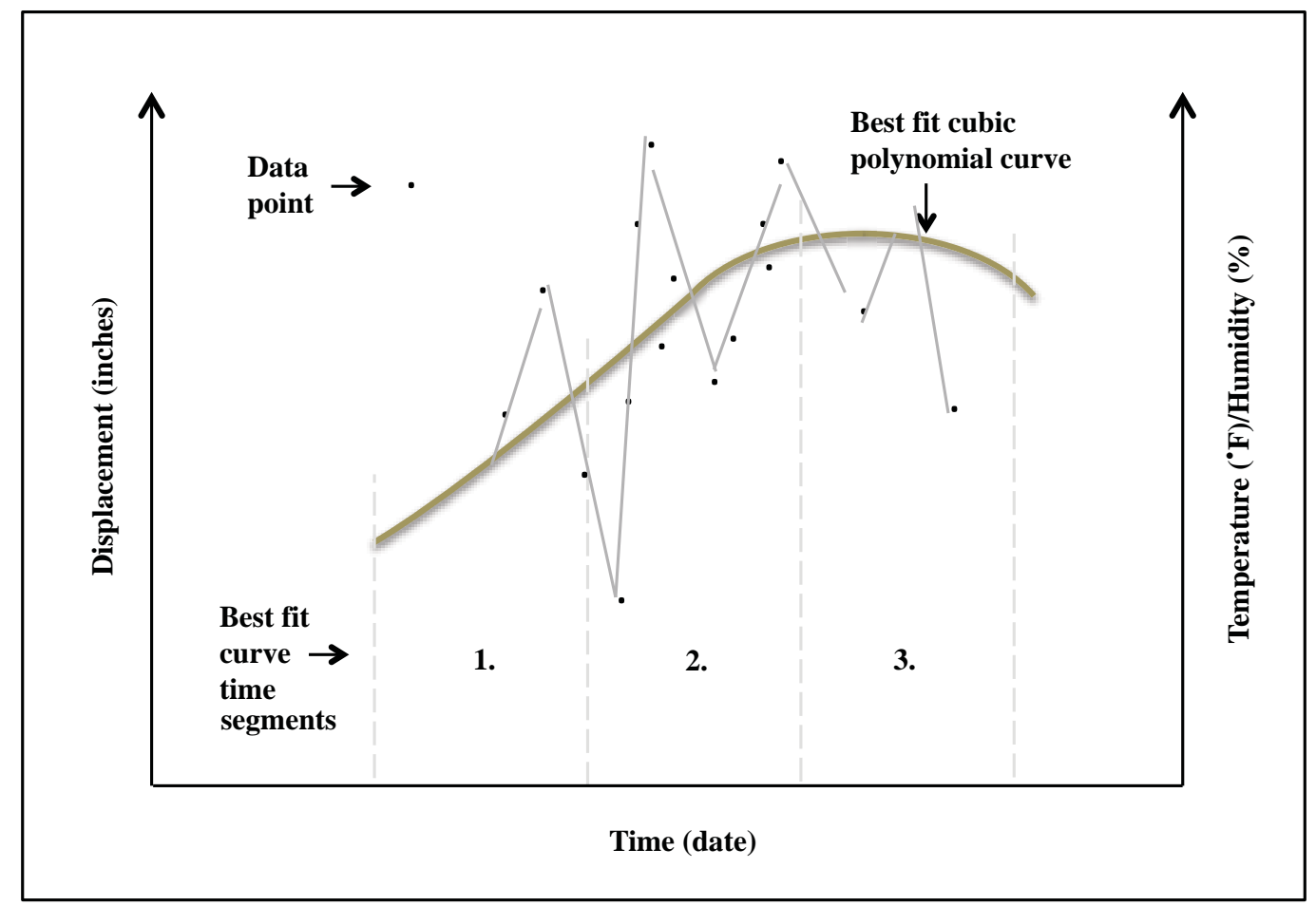

Figure 14. Best fit curve and axes definitions for study.

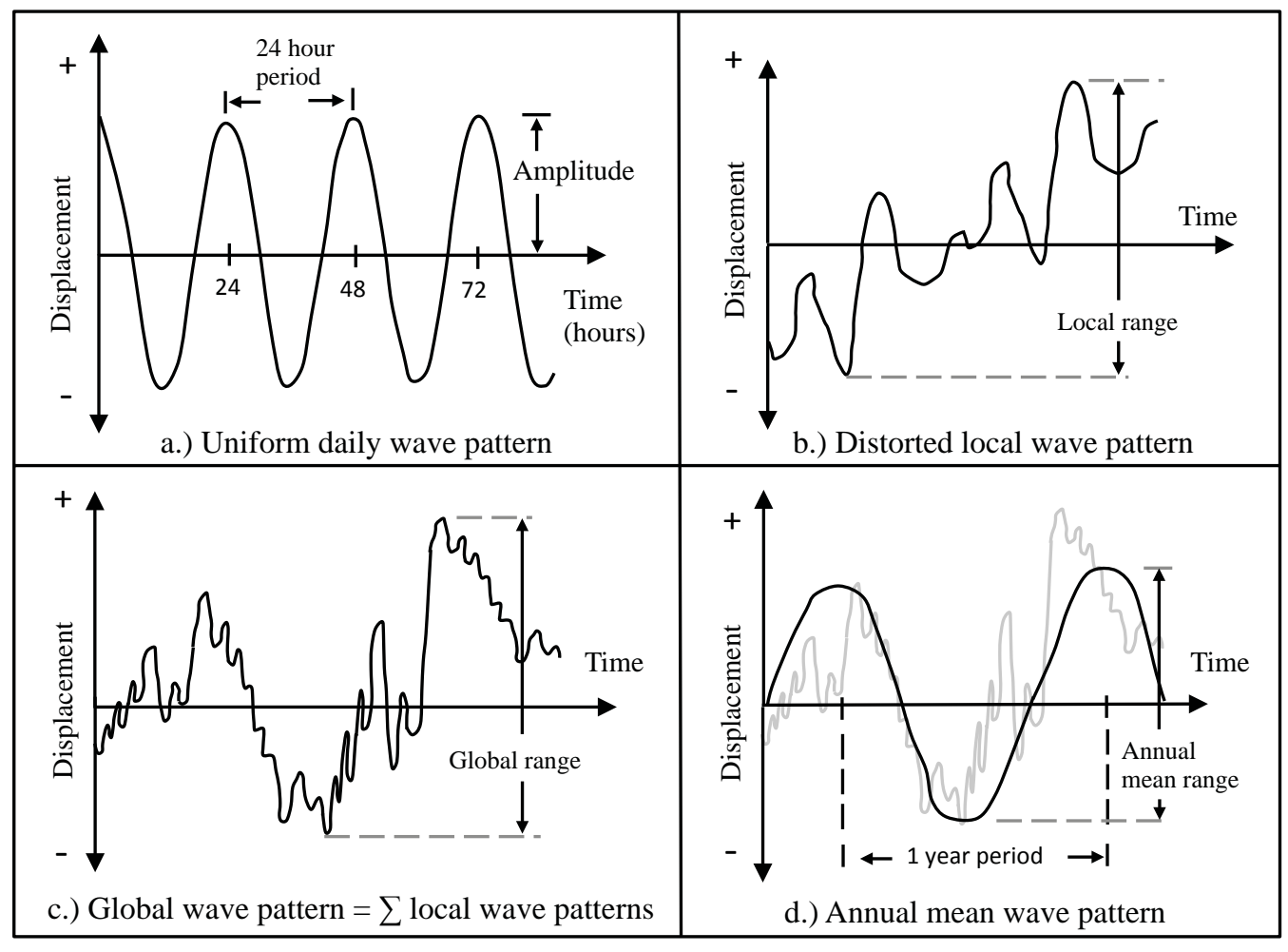

Figure 15. Wave pattern definitions. 


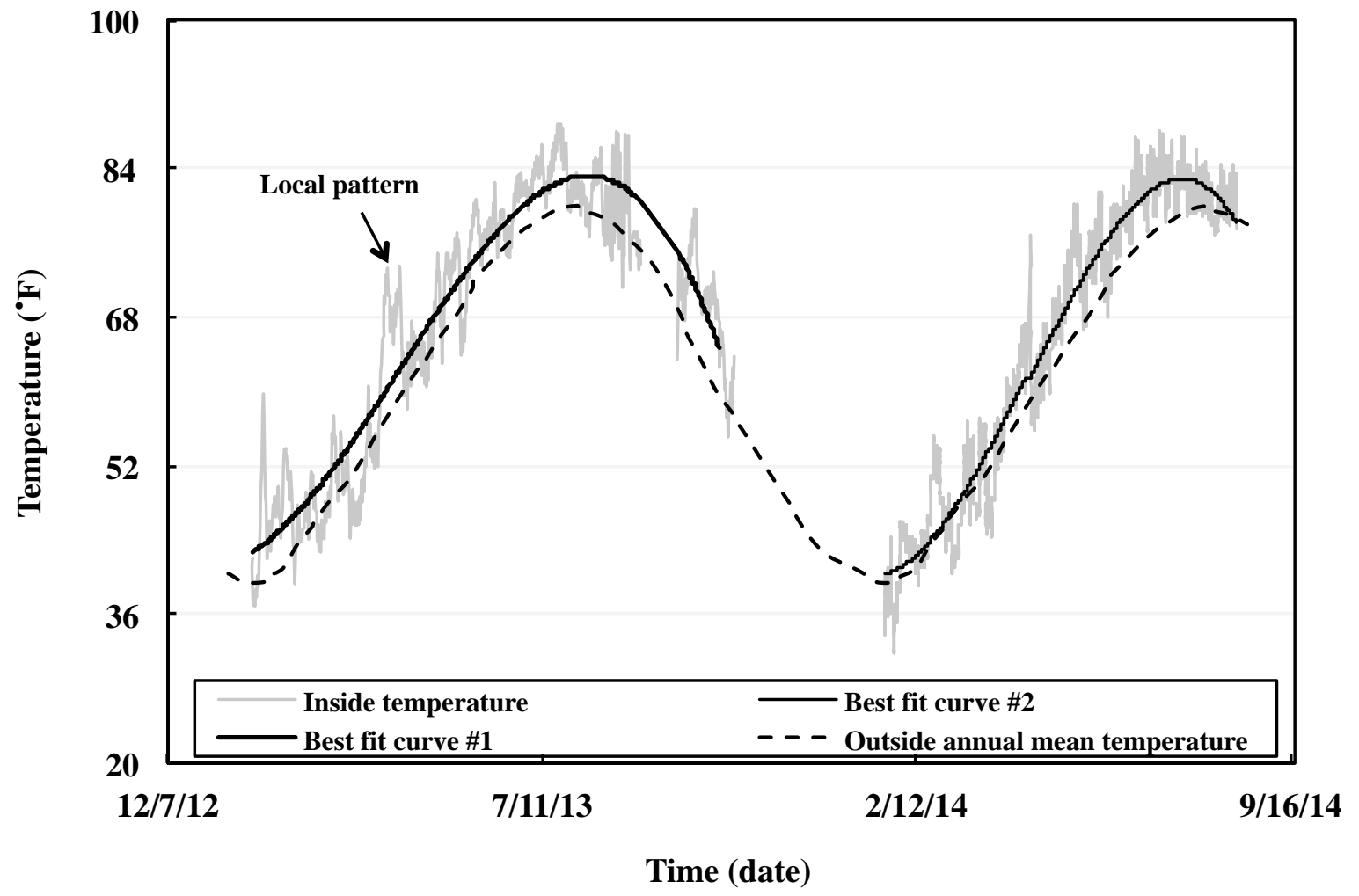

Figure 16. Inside temperature data, best fit curve, and outside annual mean temperature curve.

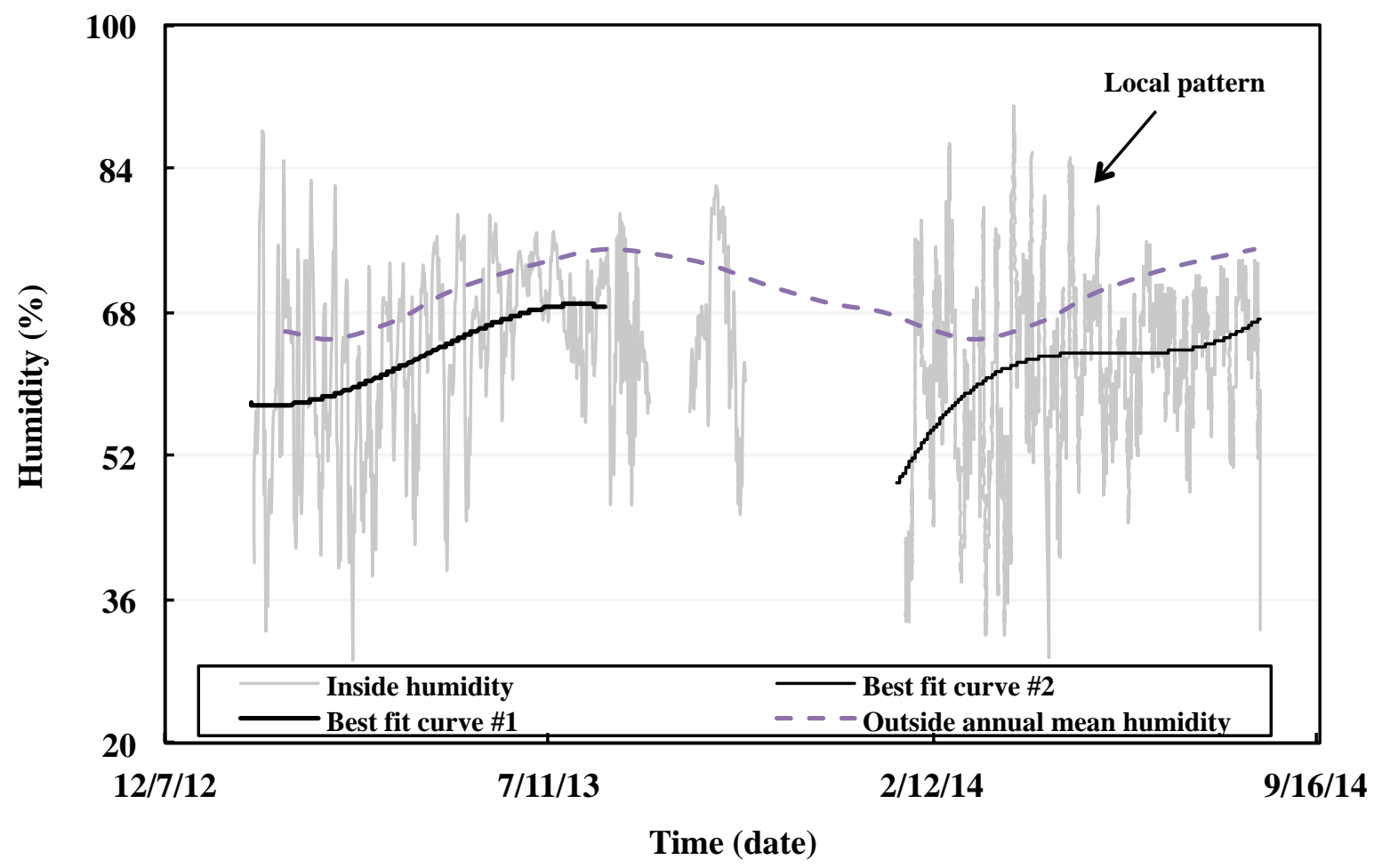

Figure 17. Inside humidity data, best fit curve, and outside annual mean humidity curve. 


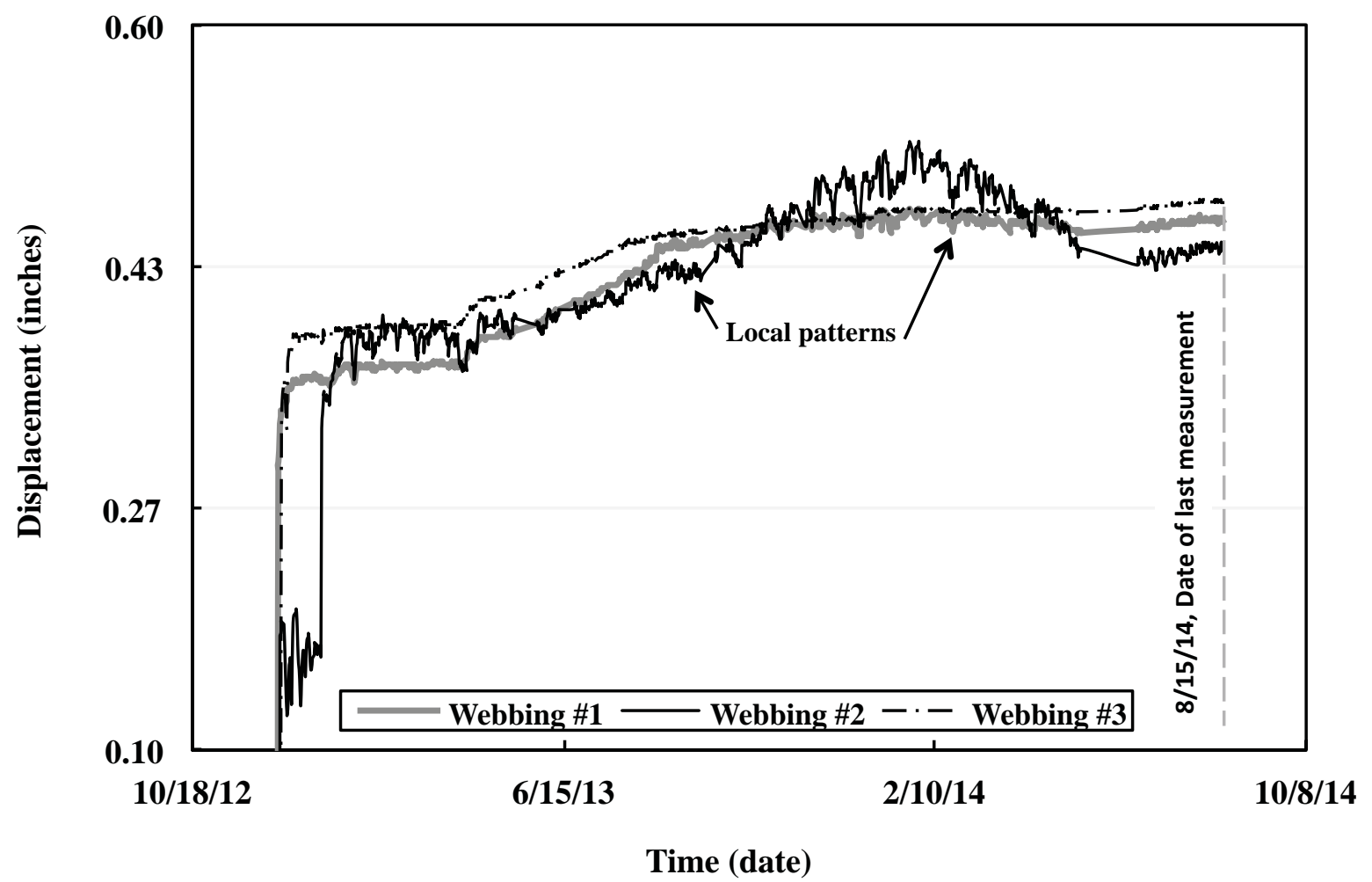

Figure 18. Creep displacements for three 6K Vectran webbings loaded to $49 \%$ UTS from group 1.

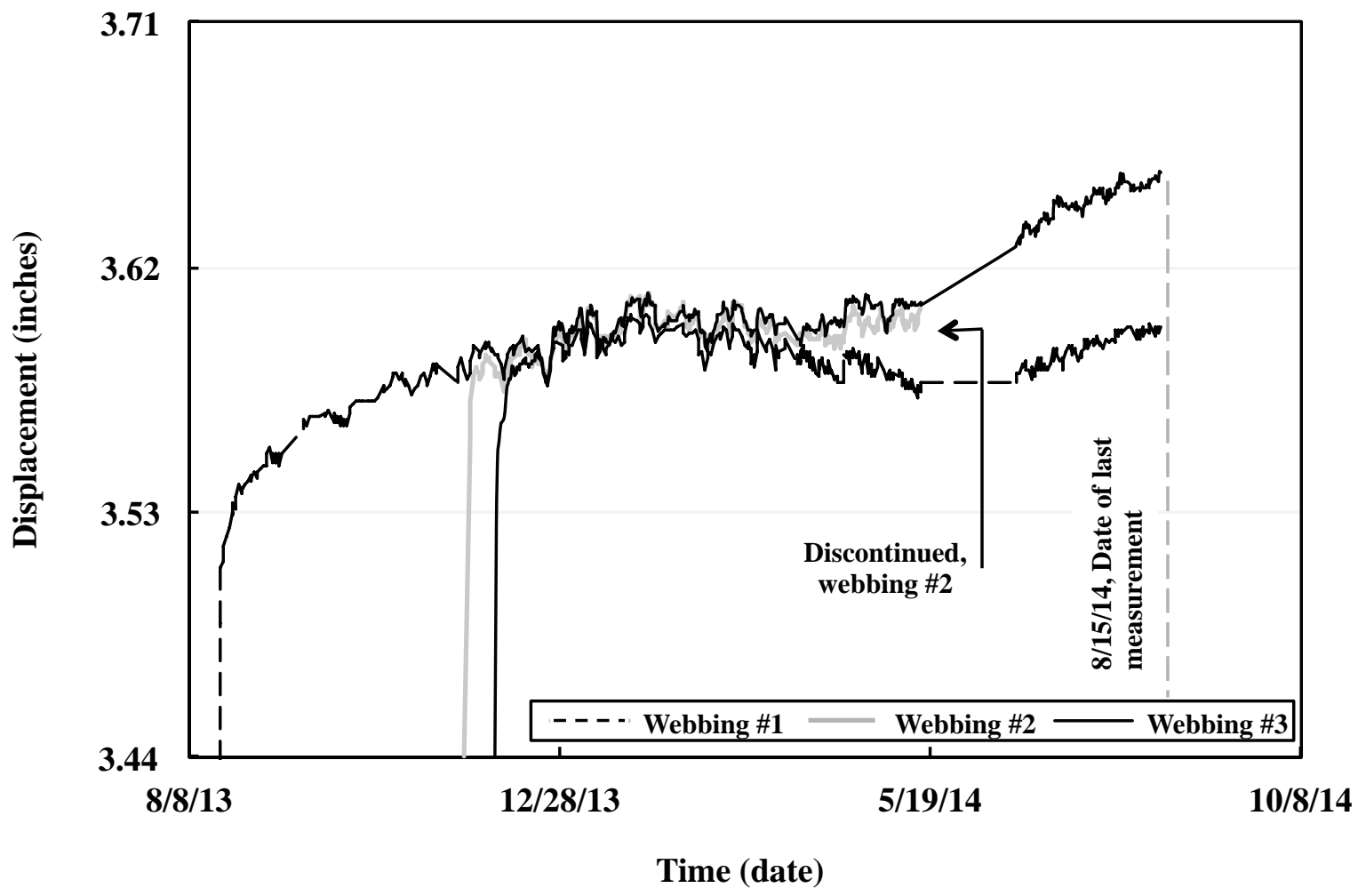

Figure 19. Creep displacements for three 6K Vectran webbings loaded to 55\% UTS from group 2. 


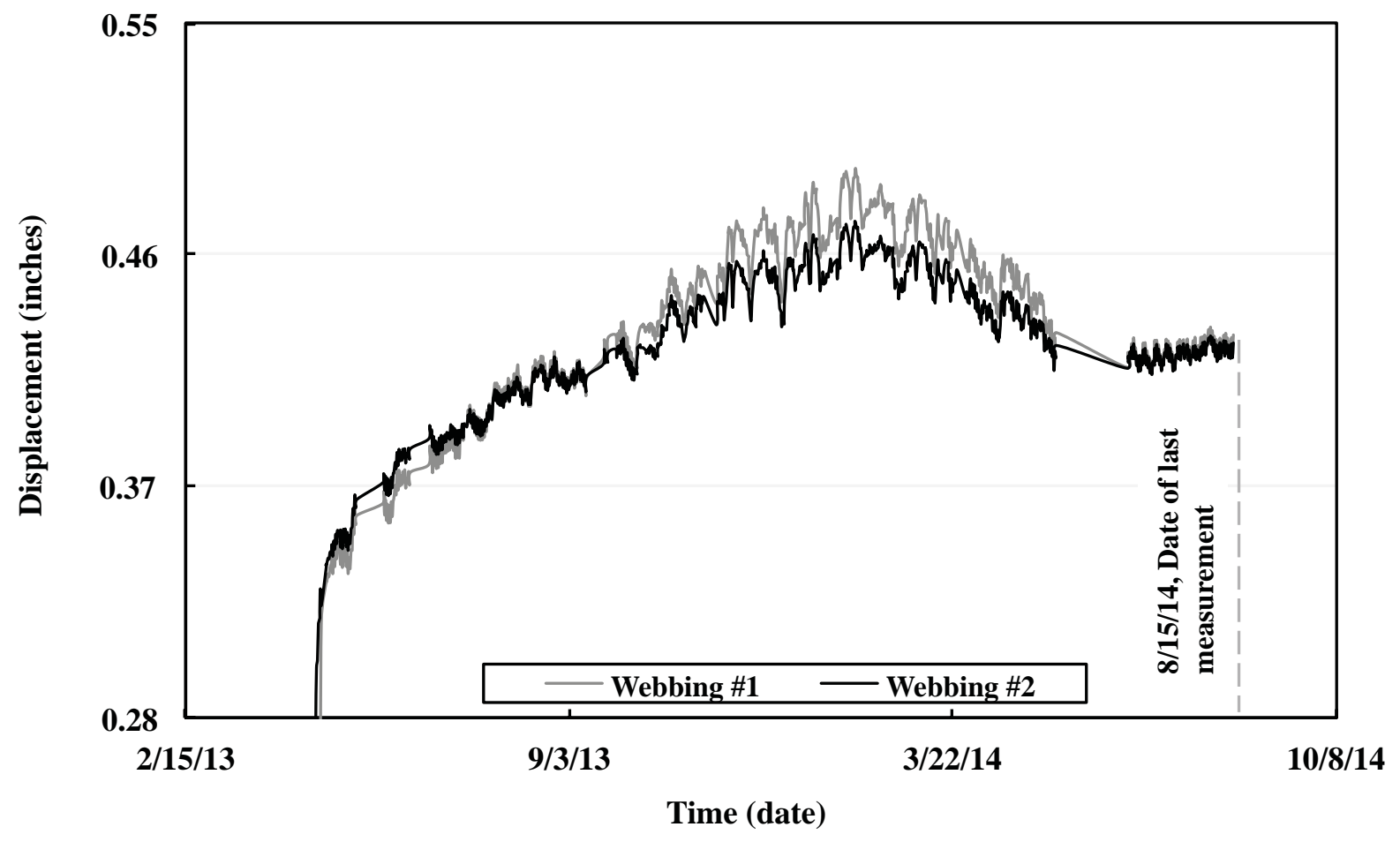

Figure 20. Creep displacements for two 12.5K Vectran webbings loaded to $22 \%$ UTS from group 3.

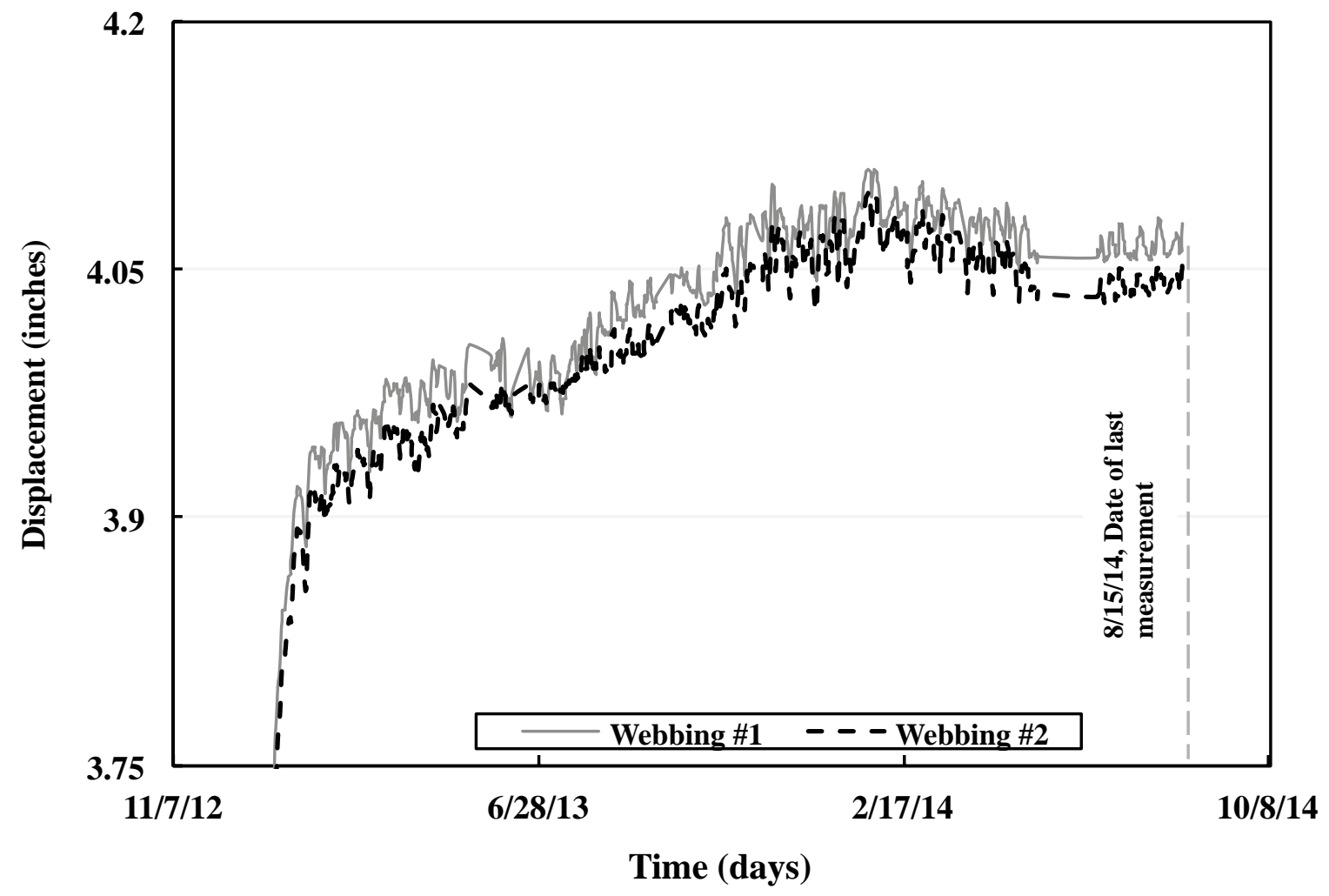

Figure 21. Creep displacements for two 6K Kevlar webbings loaded to $43 \%$ UTS from group 4. 


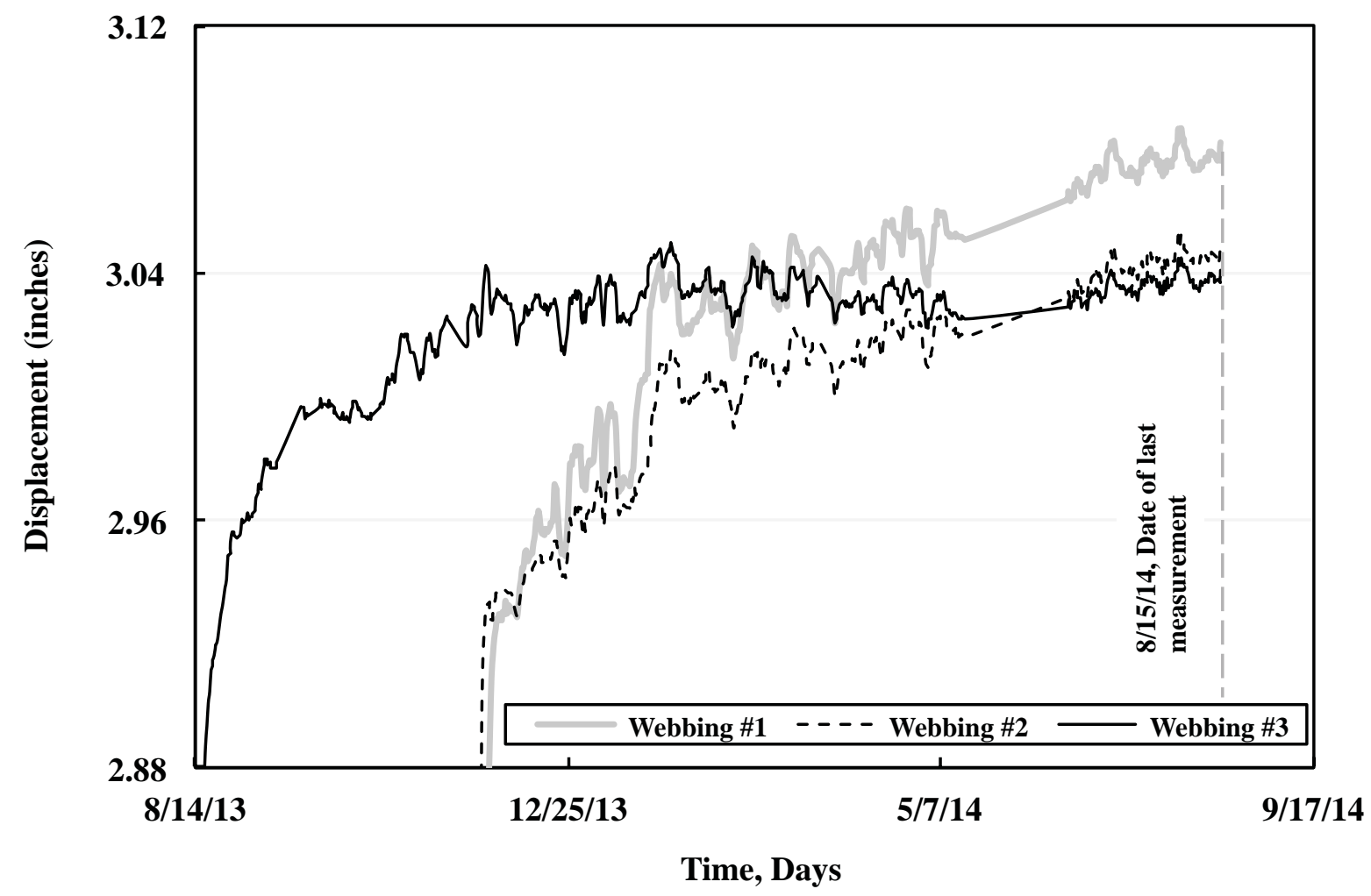

Figure 22. Creep displacements for three 6K Kevlar webbings loaded to $48 \%$ UTS from group 5.

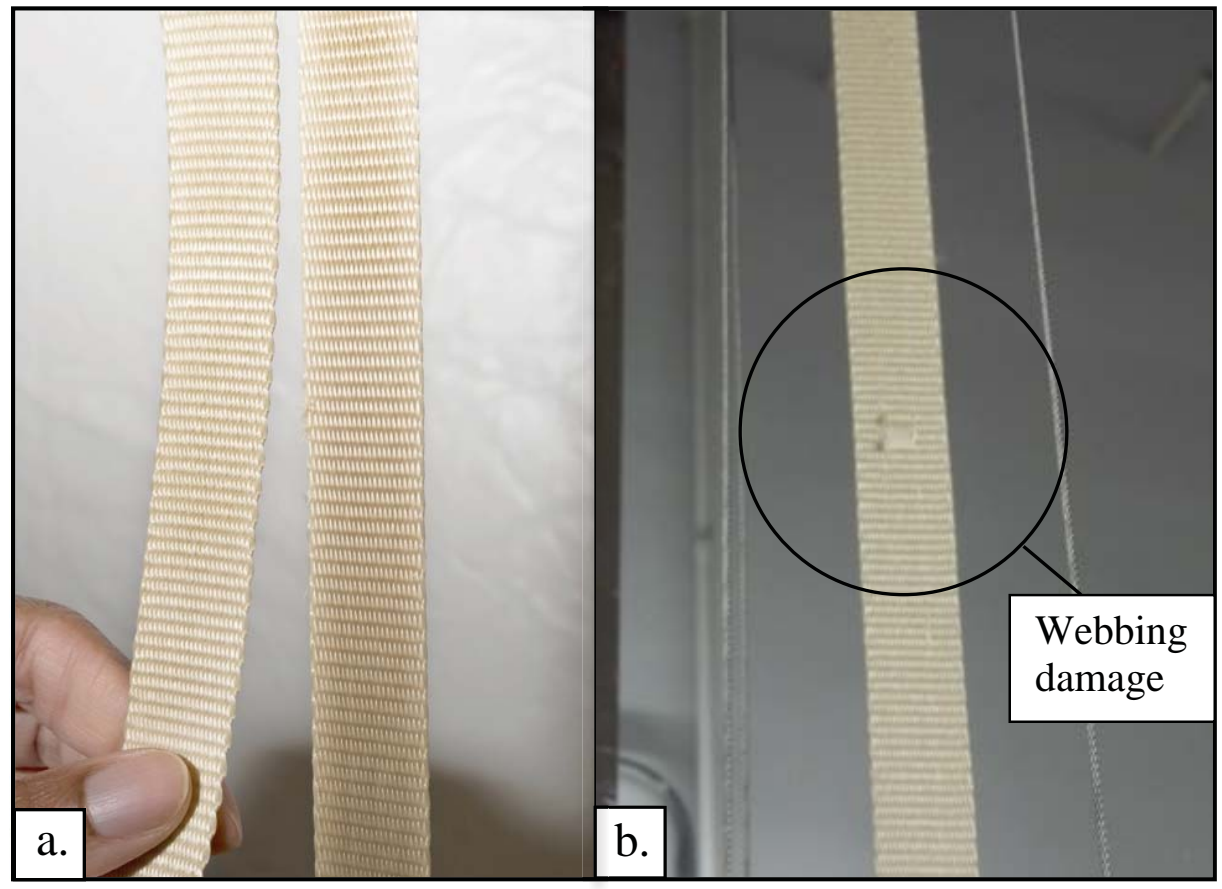

Figure 23. Photos of 6K Vectran webbings; a.) pristine and b.) damaged. 


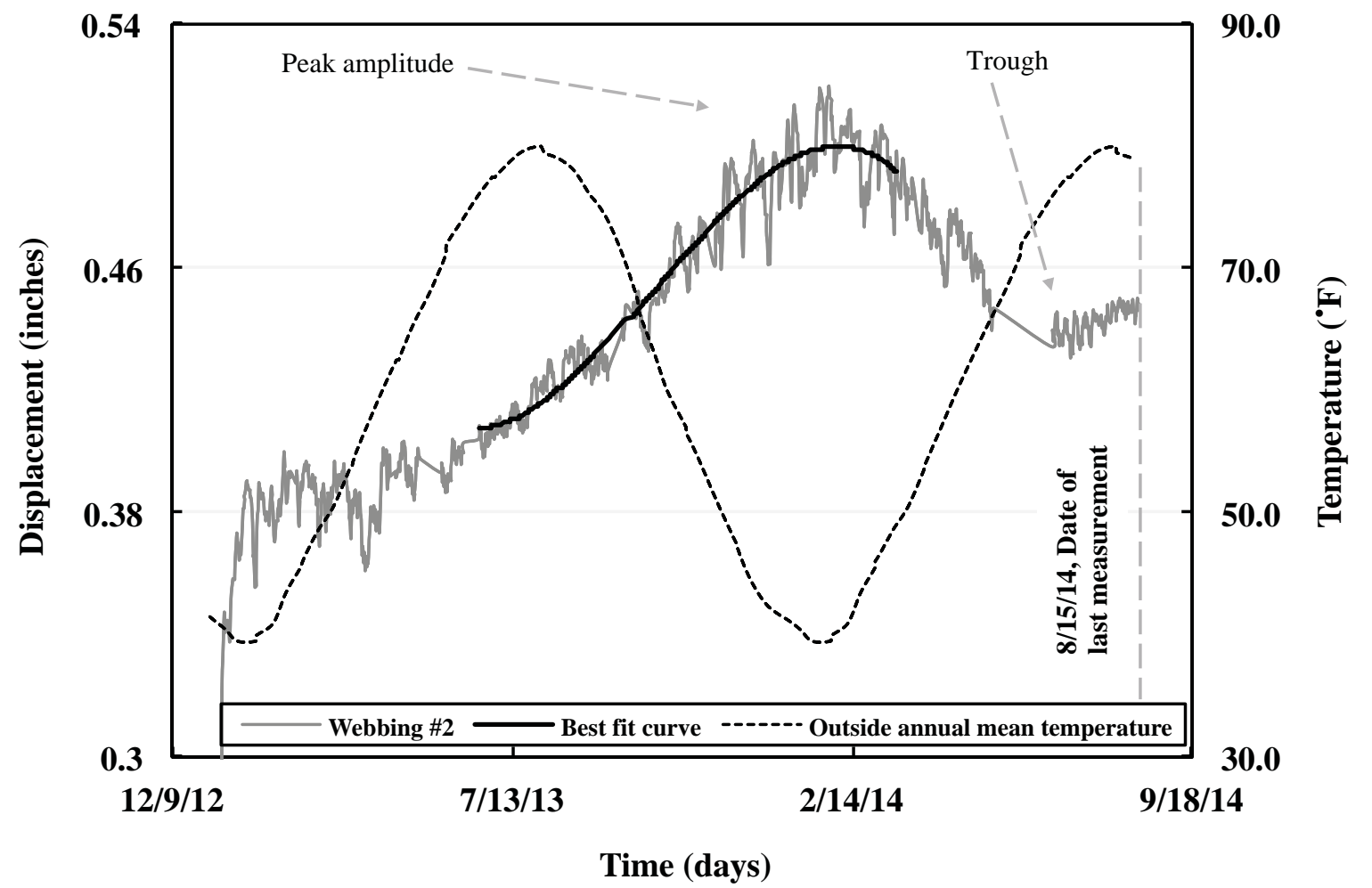

Figure 24. Creep displacement for 6K webbing \#2 loaded to 49\% UTS group 1, best fit, and outside annual mean temperature curve.

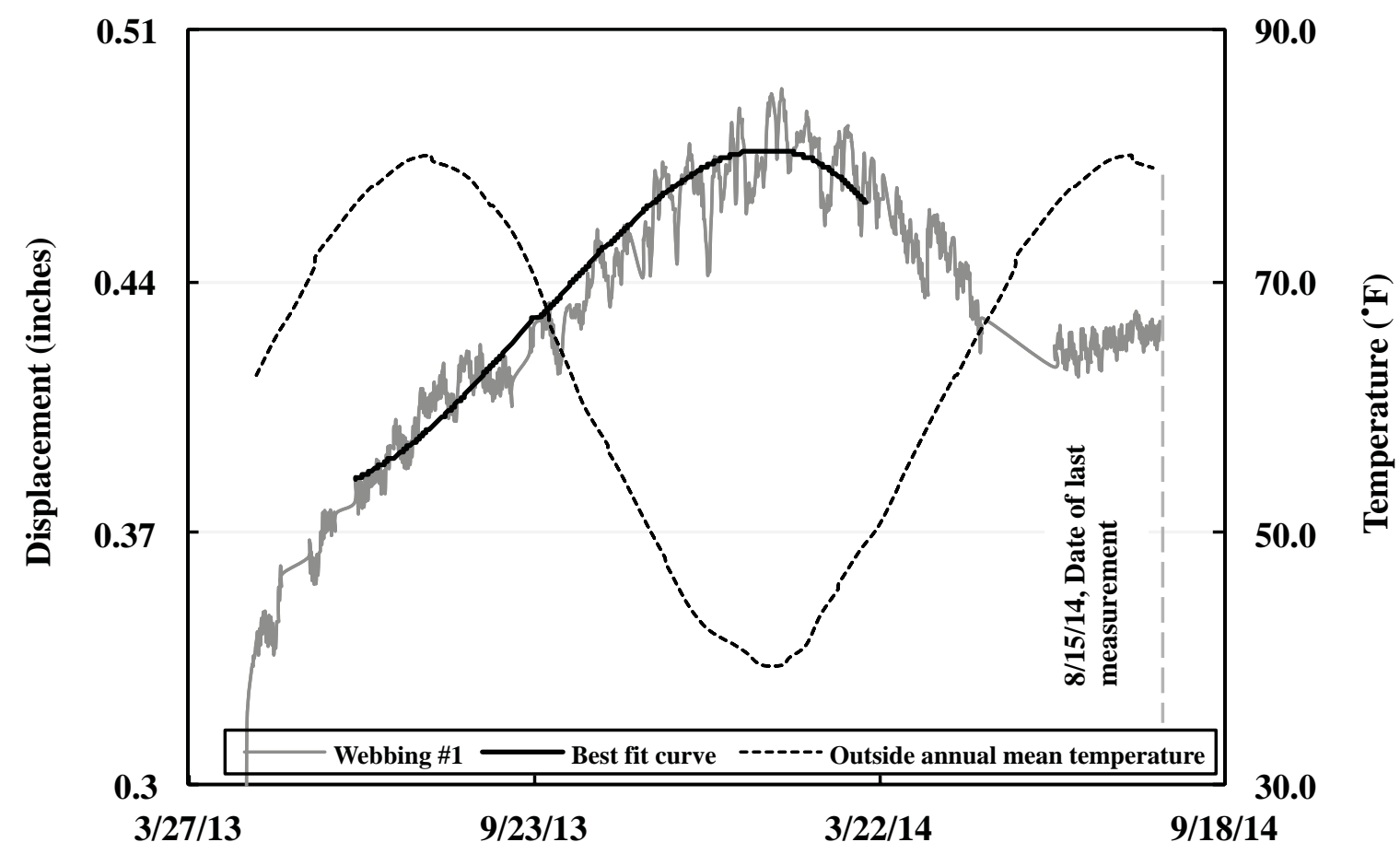

Time (days)

Figure 25. Creep displacement for 12.5K Vectrn webbing \#1 loaded to $22 \%$ UTS group 3, best fit, and outside annual mean temperature curve. 


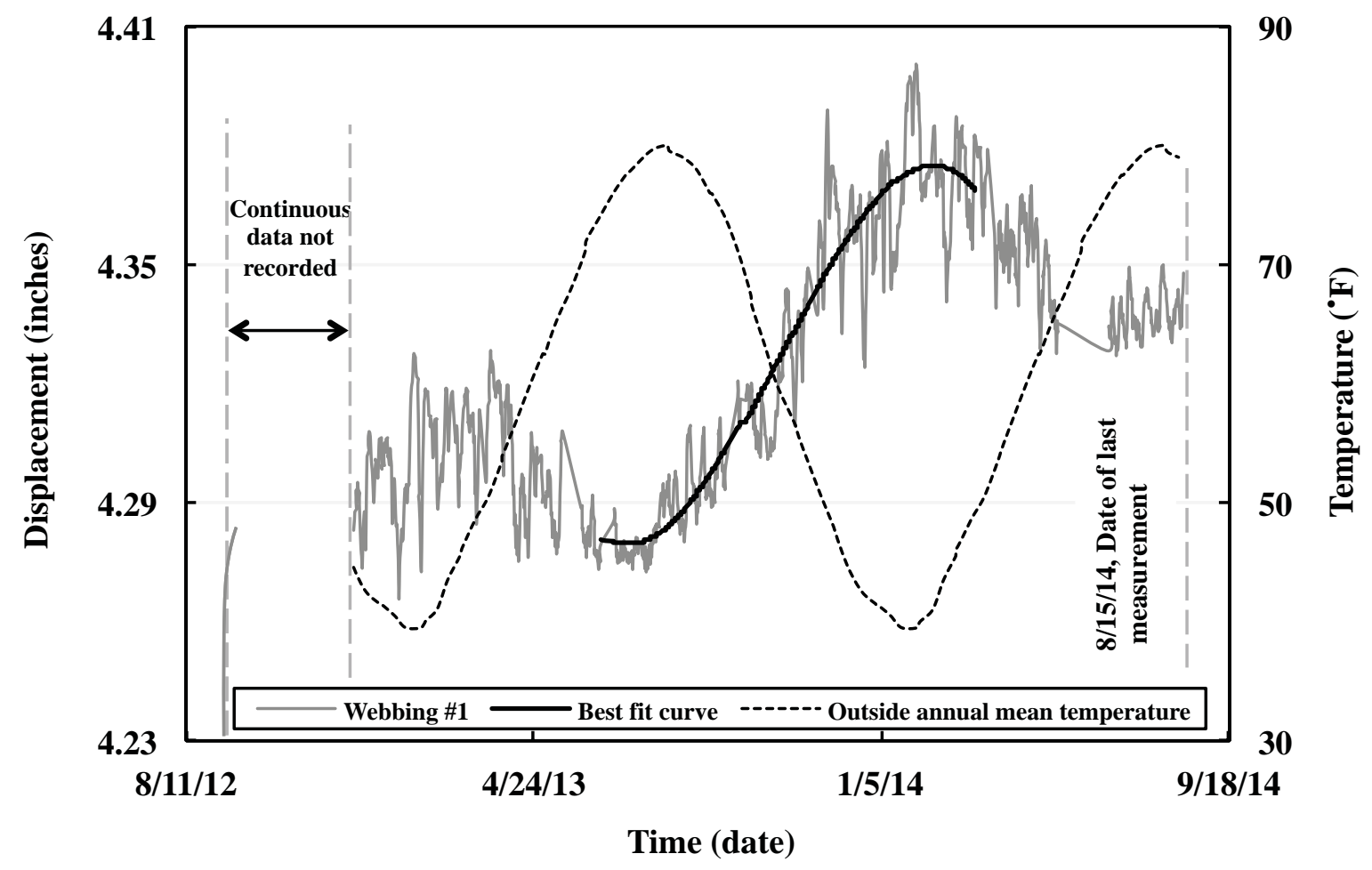

Figure 26. Creep displacement for $6 \mathrm{~K}$ Kevlar webbing \#1 loaded to $40 \%$ UTS group 4, best fit, and outside annual mean temperature curve.

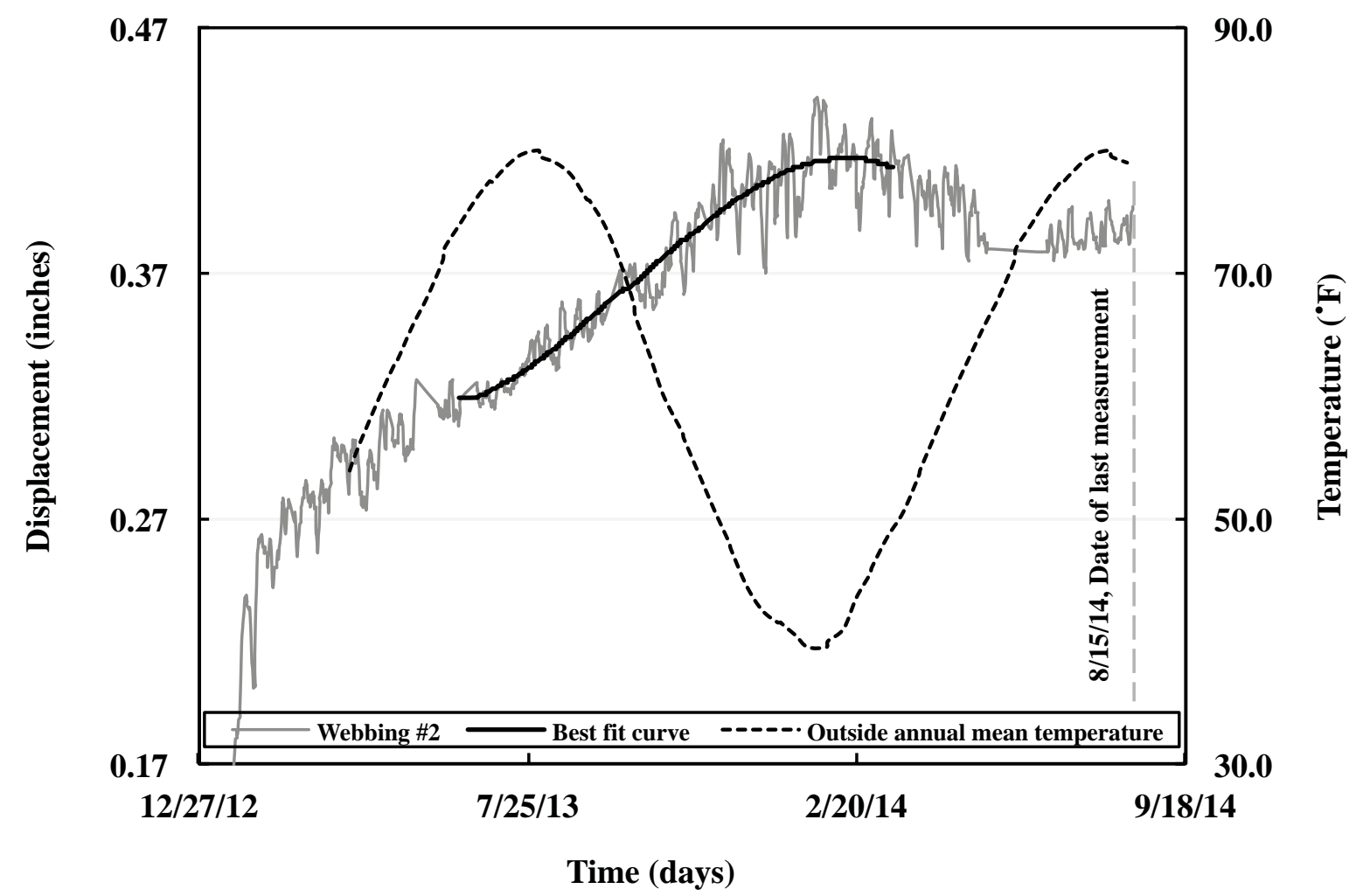

Figure 27. Creep displacement for 6K Kevlar webbing \#2 loaded to $43 \%$ UTS group 4, best fit, and outside annual mean temperature curve. 


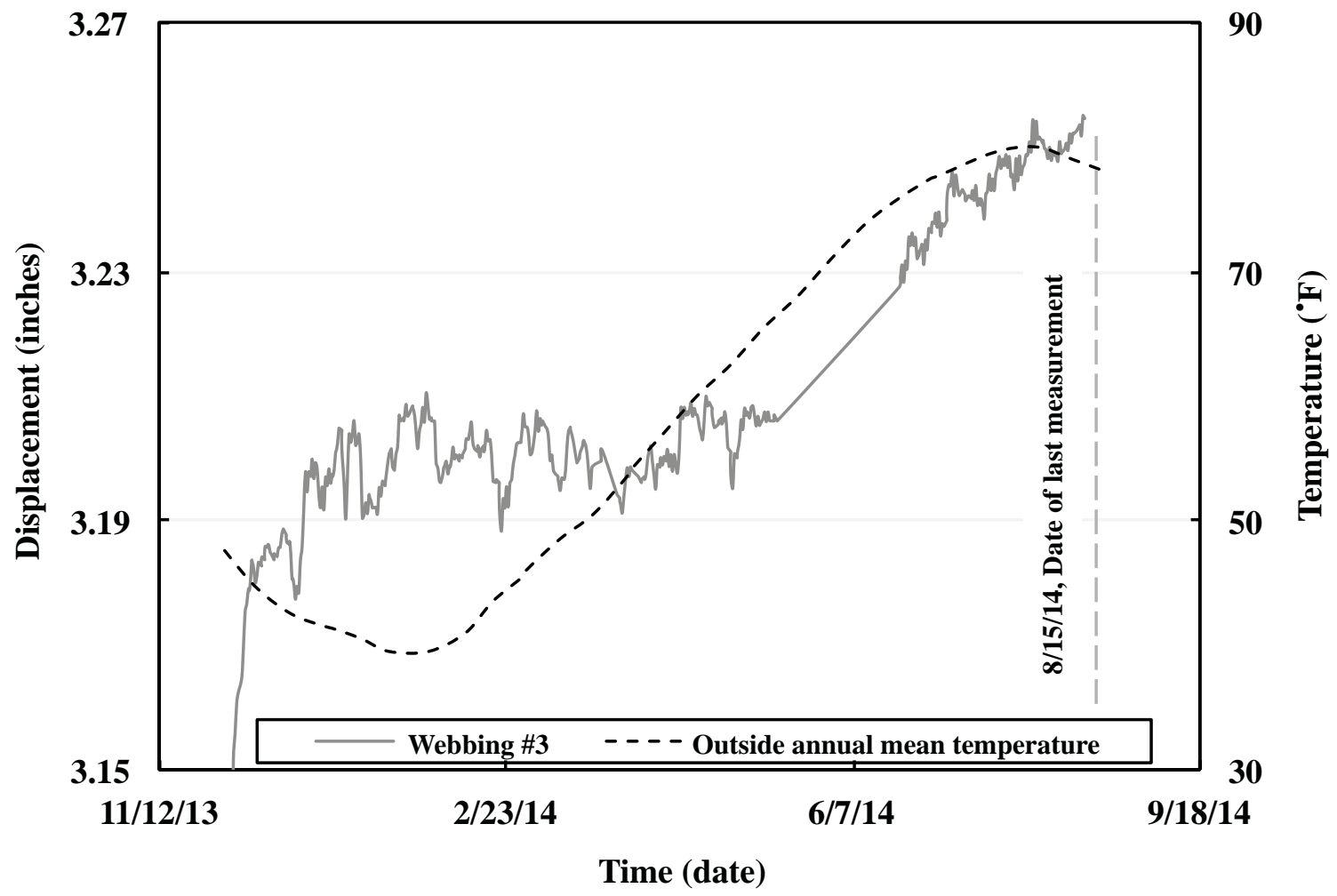

Figure 28. Creep displacement for $6 \mathrm{~K}$ Vectran webbing \#3 loaded to $59 \%$ group 2, and outside annual mean temperature curve.

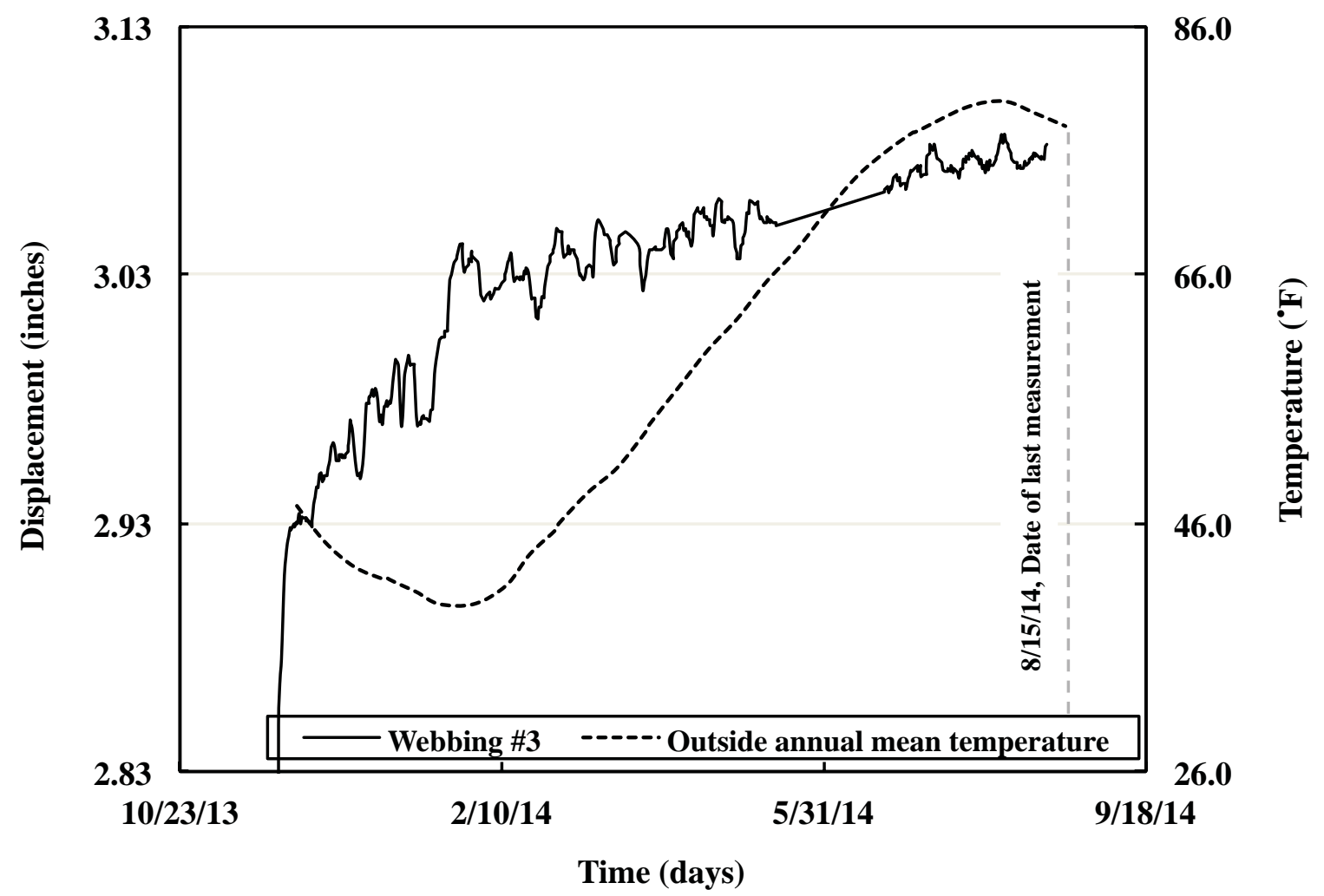

Figure 29. Creep displacement for 6K Kevlar webbing \#3 loaded to $48 \%$ UTS group 5, and outside annual mean temperature curve. 


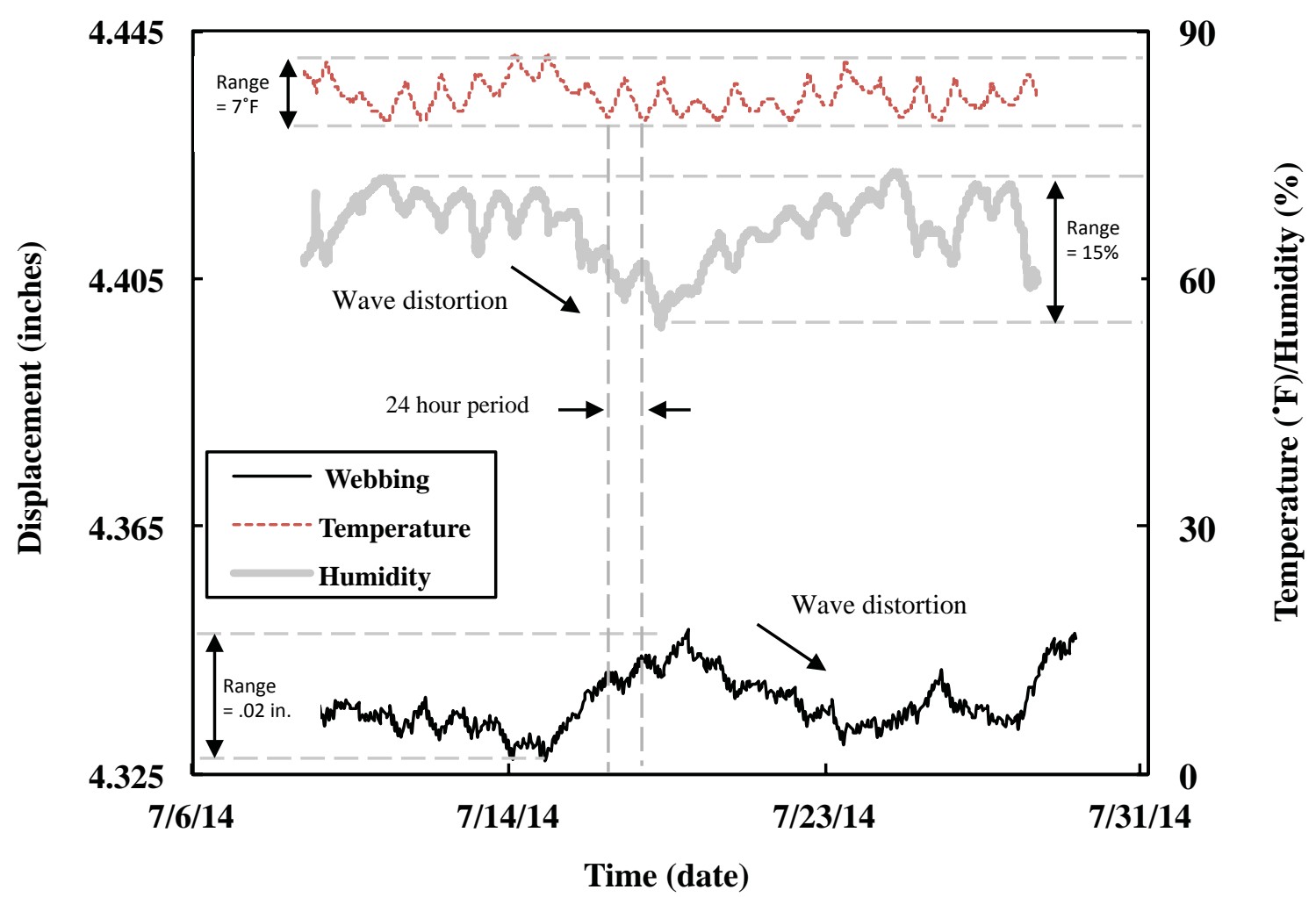

Figure 30. July 2014 temperature and humidity data, and webbing \#1 group 4 displacement data.

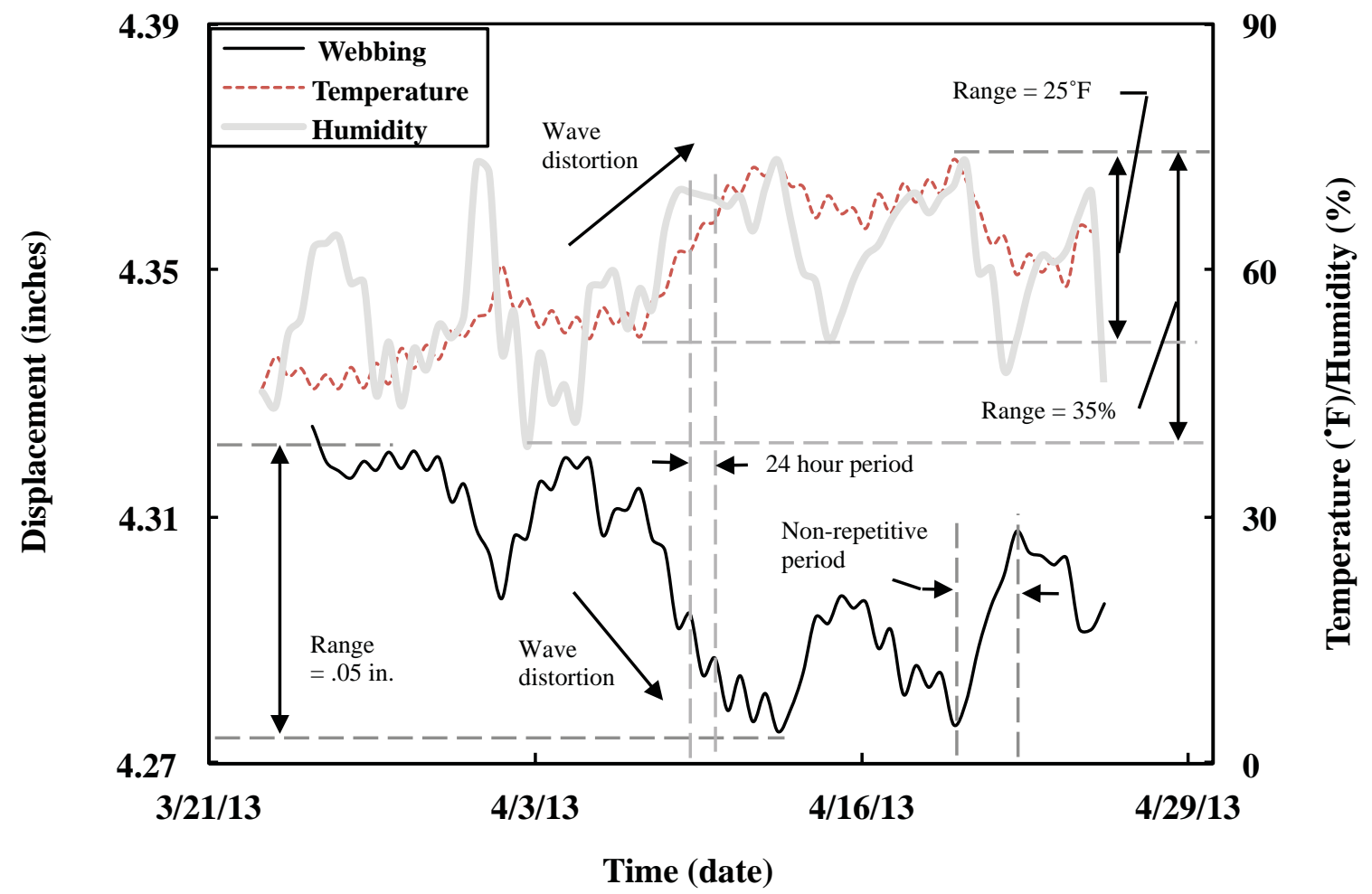

Figure 31. March/April 2013 temperature and humidity data, and webbing \#1 group 4 displacement data. 


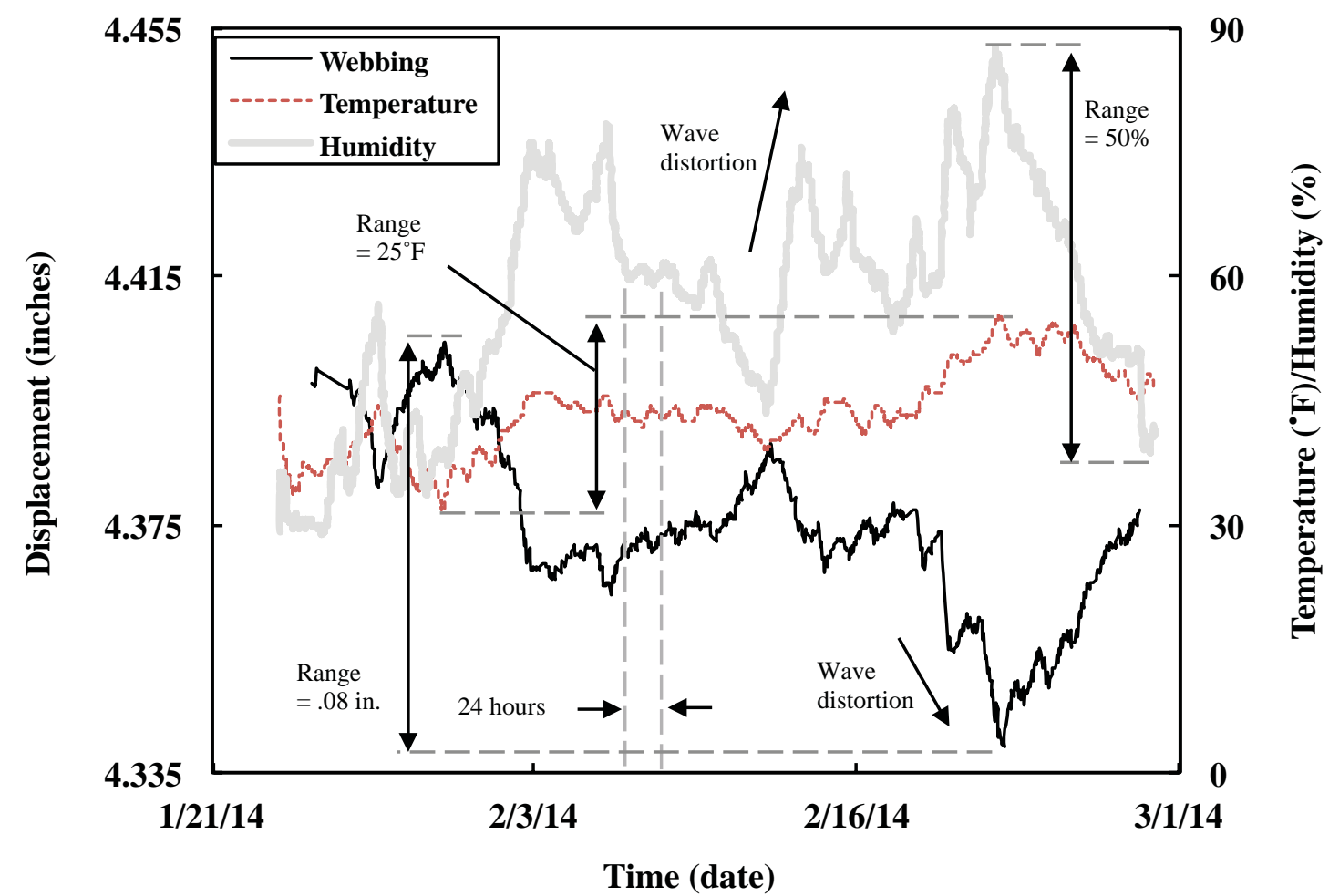

Figure 32. February 2014 temperature and humidity data, and webbing \#1 group 4 displacement data. 